\title{
Diploid and Tetraploid Cytotypes of Centaurea stoebe (Asteraceae) in Central Europe: Morphological Differentiation and Cytotype Distribution Patterns
}

\author{
Stanislav Španiel • Karol Marhold • Iva Hodálová • \\ Judita Lihová
}

(C) Institute of Botany, Academy of Sciences of the Czech Republic 2008

\begin{abstract}
The taxomically critical species Centaurea stoebe is represented in Central Europe by a diploid $(2 n=18)$ and a tetraploid $(2 n=36)$ cytotype. Their morphological differentiation and taxonomic treatment is still controversial. Karyological (chromosome numbers and flow cytometric measurements) and multivariate morphometric analyses were used here to address cytotype distribution patterns and their morphological differentiation. Material from 38 localities (771 individuals) in Slovakia, Hungary and Austria, including type localities of the names traditionally applied to the different cytotypes, was sampled and evaluated using both morphometric and karyological approaches. The morphological tendency towards cytotype differentiation is evident only at a population level, and is blurred at the level of individual plants. Diploid populations prevail in the area studied, as well as throughout Europe; mixed-cytotype populations were also found. The present data, namely the weak morphological distinction, largely sympatric occurrence of the cytotypes, and the existence of mixed-cytotype populations, favour taxonomic treatment as a single species, without recognition of infraspecific units.
\end{abstract}

Electronic supplementary material The online version of this article (doi:10.1007/s12224-008-9008-7) contains supplementary material, which is available to authorized users.

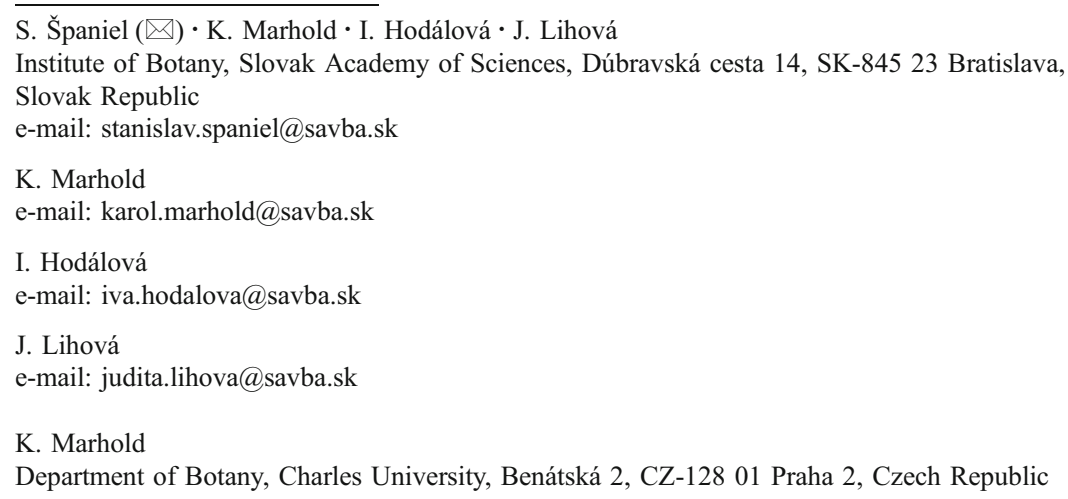


Keywords Centaurea $\cdot$ Compositae $\cdot$ Multivariate morphometrics $\cdot$ Polyploidy

\section{Introduction}

Polyploidy is recognized as an important evolutionary phenomenon and a significant source of angiosperm diversity (Soltis et al. 2003, 2004). The evolutionary consequences of polyploidization have attracted much attention, and especially in the past decade considerable progress has been achieved in the study of polyploids (reviewed e.g., by Wendel 2000; Osborn et al. 2003; Soltis et al. 2004, 2007). Coexistence of different cytotypes within a single species (without recognition of infraspecific taxa) is rather frequent (e.g. Suda 1998; Keeler and Davis 1999; Suda and Lysák 2001; Lihová et al. 2003; Trávníček et al. 2004; Perný et al. 2005; Hodálová et al. 2007; Schönswetter et al. 2007). Reproductive barriers between the cytotypes can be of different strength, and such species can bear significant evolutionary potential. Nevertheless, even if the cytotypes represent distinct biological entities, present taxonomic treatments largely rely on a morphology-based concept, and assessment of their morphological differentiation is therefore still highly relevant (Rowley 2007; Soltis et al. 2007).

Centaurea L. belongs to the plant genera, where polyploidy plays a considerable evolutionary role and causes taxonomic difficulties in many species or species groups (see e.g., Vanderhoeven et al. 2002; Koutecký 2007). This is also the case for the Central European Centaurea stoebe L. that attracted our attention. Traditionally at least two taxa occurring in Central Europe have been recognized within $C$. stoebe, treated either at the species or subspecies level, and referred to as C. australis Pančić ex A. Kern., C. biebersteinii DC., C. maculosa Lam., C. micranthos S. G. Gmel. (nom. inval.), C. rhenana Boreau, C. stoebe or combinations based on these names (Kerner 1872; Gugler 1907; Wagner 1910; Prodan and Nyárády 1964; Visjulina 1965; Soó 1970; Mądalski and Ciaciura 1972; Schubert and Vent 1976; Dostál 1989; Dostál and Červenka 1992; Adler et al. 1994; Ochsmann 2000; Simon 2000). The width of involucres and length of pappi were reported as important characters that differentiate these taxa. Because two cytotypes (diploids and tetraploids) were revealed within C. stoebe (Moore and Frankton 1954; Guinochet 1957; Baksay 1958; Skalińska et al. 1959), ploidy level used to be considered as an additional differentiating feature between these taxa (Soó 1970; Mądalski and Ciaciura 1972; Dostál 1976; Schubert and Vent 1976; Wagenitz 1987; Dostál and Červenka 1992). According to Ochsmann (2000), an important difference between the two subspecies/cytotypes of $C$. stoebe is also in their life history traits, diploids being monocarpic, and tetraploids polycarpic. Nevertheless, some authors preferred a concept of a single species (C. stoebe) with two cytotypes, without any infraspecific division (Štepánek 2002; Štepánek and Koutecký 2005). In the recent taxonomic revision of $C$. stoebe (Ochsmann 2000), tetraploids were treated as $C$. stoebe subsp. micranthos "(Gugler) Hayek" (correct name is C. stoebe subsp. australis (Pančić ex A. Kern.) Greuter), while diploids were assigned to $C$. stoebe subsp. stoebe and $C$. stoebe subsp. serbica (Prodan) Ochsmann. The latter subspecies does not occur in Central Europe and is endemic to Serbia (Pirot), Bulgaria and Greece.

Centaurea stoebe is common in Europe extending eastwards to Asia (Meusel and Jäger 1992). In addition, it occurs as an alien plant in North America, known under 
the synonym $C$. maculosa Lam. Only tetraploids were reported from that area. It is reported as a serious invasive weed in the USA and Canada, and numerous papers were published about its environmental impact, and monitoring of its occurrence and spread (e.g. Hook et al. 2004; Lutgen and Rillig 2004; Emery and Gross 2005; Perry et al. 2005; Crowe and Bourchier 2006).

No other ploidy levels besides diploids $(2 n=18)$ and tetraploids $(2 n=36)$ are known within $C$. stoebe, but the occurrence of B chromosomes was reported (Skalińska et al. 1959; Löve and Löve 1961b; Agapova et al. 1990; Lövkvist and Hultgård 1999; Ochsmann 1999; Nagel 2000). Before the investigations done by Ochsmann (1999, 2000), who reported numerous chromosome number records for C. stoebe from Italy, Germany, Austria, Hungary and Switzerland (32 localities altogether), the cytogeography of this species was poorly investigated in Central Europe. For the area of Slovakia, only two chromosome number records proving the occurrence of both cytotypes were reported (Záborský 1970). There are no studies addressing the origin of polyploid populations of $C$. stoebe, whether they represent allo- or autopolyploids.

Until recently, some (mainly Central European) authors treated C. stoebe within the genus Acosta Adans. (Dostál 1989; Dostál and Červenka 1992; Marhold and Hindák 1998). The separation of the genus Acosta resulted from a split of the heterogeneous genus Centaurea as proposed by Löve and Löve (1961a) and followed by other authors (Holub 1972, 1973, 1974; Soják 1972; Dostál 1973). Following recent molecular phylogenetic studies in Centaurea (Susanna et al. 1995; Wagenitz and Hellwig 1996; Garcia-Jacas et al. 2000, 2001, 2006), new generic limits were suggested (Greuter et al. 2001). A separate genus Rhaponticoides Vaill., previously known as Centaurea sect. Centaurea, was proposed. It is phylogenetically distinct from the generic core and includes the original type species of the genus Centaurea (Greuter 2003; Greuter et al. 2005). Therefore, a proposal was published and later approved, to conserve the name Centaurea with a new type, namely C. paniculata L. (Greuter et al. 2001; Brummitt 2004), a species traditionally placed in Acosta. Following this treatment, the name Acosta could not be applied for a separate genus, even if a narrow concept of the genus Centaurea is applied.

The present study focuses on $C$. stoebe in Slovakia and adjacent territories, including material from type localities of the names $C$. stoebe and $C$. australis. Based on the current knowledge on this species, the following questions were asked: $i$ ) Are diploids and tetraploids morphologically differentiated? $i$ ) If so, which morphological characters contribute to their differentiation? iii) Which cytotypes occur at the type localities of $C$. stoebe and $C$. australis? iv) Do different cytotypes co-occur at the same localities, and if so, how often? $v$ ) Are there any indications of ecological and/or chorological differentiation of the cytotypes?

\section{Material and Methods}

\section{Plant Material}

Plant material from 40 localities of Centaurea stoebe originating from Slovakia (35), Hungary (4) and Austria (1) was collected (Table 1, Fig. 1). Two population samples 
Table 1 Origin of the plant material used in the present study

Nr. Locality

DNA ploidy

level

$2 n$

$2 n \sim 2 x \quad 2 n \sim 4 x$

1 SK, Devínska Kobyla, Bratislava-Devínska Nová Ves, stone quarry Waitov lom, ca. $300 \mathrm{~m}$ a. s. 1., 7867b, 16 Aug 2004, Sک̌

2 SK, Ipel'sko-rimavská brázda, Malý Krtíš, E of the village, near the vineyards, $220 \mathrm{~m}$ a. s. 1., 7882a, 15 Aug 2004, SS̆

3 SK, Podunajská nížina, Bratislava-Čunovo, around the reservoir near the city quarter, $120 \mathrm{~m}$ a. s. 1., 7969c, 17 Aug 2004, SŠ

4 SK, Tríbeč, Nitra, Zobor hill, 588 m a. s. 1., 7674d, 19 Aug 2004, SS̆

5 SK, Malé Karpaty, Cachtice, hill near the ruin of the Čachtický hrad castle, $300 \mathrm{~m}$ a. s. 1., 7272d, 20 Aug 2004, SS̆

6 SK, Burda, Kamenica nad Hronom, 290 m a. s. 1., 8178c, 21 Aug 2004, Sک̌

7 SK, Podunajská nížina, Štúrovo, beside the road near the railway station, $120 \mathrm{~m}$ a. s. 1., 8278a, 21 Aug 2004, Š̆

8 SK, Ipel'sko-rimavská brázda, Modrý Kameň, around the calvary in the forest steppe Nature Reserve Modrokamenská lesostep, 420 m a. s. 1., 7782c, 23 Aug 2004, SŠ

9 SK, Ipel'sko-rimavská brázda, Plášt'ovce, deforested part of the hill Š́pka, 240 m a. s. 1., 7879b, 24 Aug 2004, Sک̌

10 SK, Ipel'sko-rimavská brázda, Fil'akovské Kováče, sand pit in the SW part of the village, $200 \mathrm{~m}$ a. s. 1., 7784b, 24 Aug 2004, Sک̌

11 SK, Slovenský kras, Plešivec, Koniarska planina plateau, National Nature Reserve Pod Strážnym hrebeňom, 360 m a. s. 1., 7488c, 30 Aug 2004, $S \check{S}$

12 SK, Slovenský kras, Dlhá Ves, slope of former National Nature Reserve Domické škrapy, above the cave Domica, 390 m a. s. 1., 7588b, 6 Sept 2004, SS̆

13 AU, Niederösterreich, Hinterbrühl near the town Mödling, rocks in the stone quarry, 19 Aug 2005, SŠ \& I. Hodálová; Centaurea stoebe L., locus classicus

14 SK, Turčianska kotlina, Mošovce, near the border of the national park Vel'ká Fatra, $500 \mathrm{~m}$ NE of the camping place Drienok, 520 m a. s. 1., 7079c, 9 Aug 2005, SS̆

15 SK, Strážovské a Súl'ovské vrchy, Trenčín, in the area of the Trenčiansky hrad castle, $280 \mathrm{~m}$ a. s. 1., 7174a, 7 Oct 2004, SS̆

16 SK, Malé Karpaty, Plavecké Podhradie, rocks in the S part of the National Nature Reserve Pohanská, 350 m a. s. 1., 7569b, 23 Jul 2005, Sک̌

17 HU, Heves, Mátra, Bodony, $\mathrm{N}$ of the village, hayfield near the settlement, 26 Jul 2005, SŠ \& I. Hodálová;

Centaurea australis Pančić ex A. Kern., locus classicus

18 HU, Komárom-Esztergom, Mocsa, sand steppe grassland Béla puzsta, 26 Jul 2005, SŠ \& I. Hodálová

19 HU, Nógrád, between Ságújfalu and Kishartyán, grassy slopes near the road, 26 Jul 2005, SS \& I. Hodálová

20 HU, Komárom-Esztergom, Komárom, right bank of the river Danube, near the railway station, 26 Jul 2005,

SŠ \& I. Hodálová

21 SK, Malé Karpaty, Hradište pod Vrátnom, meadow on the hills in the SE part of the village, $340 \mathrm{~m}$ a. s. 1., 7370d, 1 Aug 2005, SS̆

22 SK, Považský Inovec, Lúka, about $100 \mathrm{~m}$ of the village in the valley Lúčanská dolina near the touristic path to Tematín castle, ca. $260 \mathrm{~m}$ a. s. 1., 7373a, 3 Aug 2005, SS̆

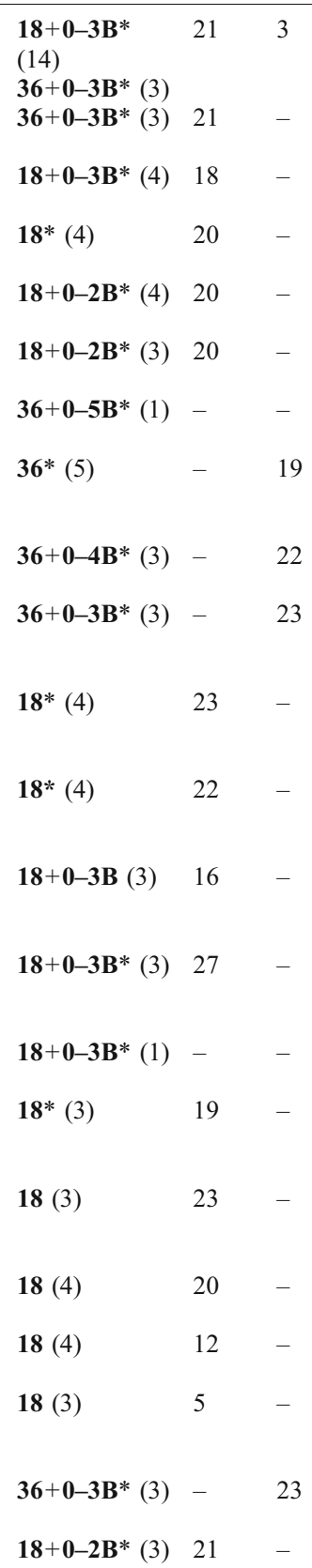


Table 1 (continued)

Nr. Locality

DNA ploidy

level

$2 n$

$2 n \sim 2 x \quad 2 n \sim 4 x$

23 SK, Záhorská nížina, Závod, W part of the village, near the road parallel with the railway, ca. $160 \mathrm{~m}$ a. s. 1 ., 7468c, 5 Aug 2005, SS̆

24 SK, Záhorská nížina, Plavecký Štvrtok, S of the village, close to the fishpond, ca. $160 \mathrm{~m}$ a. s. 1., 7668a, 5 Aug 2005, $S \check{S}$

25 SK, Podunajská nížina, Bratislava-Podunajské Biskupice, Kopáčsky ostrov island, ca. 135 m a. s. 1., 7968b, 6 Aug 2005, Š̆

26 SK, Podunajská nížina, Tlmače, $\mathrm{N}$ of the village, stone quarry Kusá hora, 200 m a. s. 1., 7777a, 10 Aug 2005, Š́

27 SK, Slovenské stredohorie, Vígl'aš, stone quarry in the village, ca. $360 \mathrm{~m}$ a. s. 1., 7481b, 12 Aug 2005, SS̆

28 SK, Záhorská nížina, Skalica, Veterník hill, above vineyards, 300 m a. s. 1., 7169c, 17 Aug 2005, Š́, O. Ťavoda \& E. Michalková

29 SK, Záhorská nížina, Gajary, beside the levee near the river Morava, about $2 \mathrm{~km}$ W of the village, $150 \mathrm{~m}$ a. s. 1., 7567a, 17 Aug 2005, Š́, O. Ťavoda \& E. Michalková

30 SK, Podunajská nížina, Mužla, settlement of Čenkov, ruderal site near the settlement, ca. 108 m a. s. 1., 8277a, 18 Aug 2005, Š́

31 SK, Podunajská nížina, Chotín, sandy area NW of the village, 115 m a. s. 1., 8175 c, 18 Aug 2005, Š́

32 SK, Podunajská nížina, Dlhá nad Váhom, levee near the left side of the river Váh, $115 \mathrm{~m}$ a. s. 1., 7873a, 18 Aug 2005, SS̆

33 SK, Muránska planina, Tisovec, NE of the town, hayfield above the stone quarry, ca. $520 \mathrm{~m}$ a. s. 1., 7385b, 23 Aug 2005, Sک̌

34 SK, Slovenský kras, Jelšavská Teplica, S of the village, Muteň hill, steep rocks near road to the village, $400 \mathrm{~m}$ a. s. 1., 7487b,

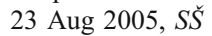

35 SK, Slovenský kras, Turňa nad Bodvou, ruderal sites at the castle ruin, $360 \mathrm{~m}$ a. s. $1 ., 7391 \mathrm{c}, 23$ Aug 2005, Sک̌

36 SK, Východoslovenská nížina, Streda nad Bodrogom, SE of the village, among vineyards on Tarbucka hill, $160 \mathrm{~m}$ a. s. 1., 7696b, 24 Aug 2005, Š́

37 SK, Východoslovenská nížina, Malý Horeš, N of the village, meadow W of the hill Vel'ký kopec, $120 \mathrm{~m}$ a. s. 1., 7597d, 24 Aug 2005, Sک̌

38 SK, Vihorlatské vrchy, Vinné, ruderal sites at the castle ruin, 325 m a. s. 1., 7197d, 25 Aug 2005, Š́

39 SK, Východné Beskydy, Sedliská, N of the village, ruderal sites at the castle ruin Čičava, $200 \mathrm{~m}$ a. s. 1., 7096c, 26 Aug 2005, SŠ

40 SK, Slanské vrchy, Kapušany, the castle hill of Kapušiansky hrad, 400 m a. s. 1., 6993b, 27 Aug 2005, Š́

$\mathbf{8}+\mathbf{0}-\mathbf{2 B} *(3) \quad 20$

19 (1)

18+0-3B* (16) $22 \quad 3$

36 (3)

18+0-3B* 29

18 (3) $21-$

36* (3) $\quad-\quad 17$

36+0-3B* (3) - 20

18+0-3B* (3) $22=$

36+0-2B* (3) - 11

18+0-2B* (3) 21

18+0-3B* (3) 19

18+0-1B* (3) 17

18* (3) 2

18+0-1B* (3) 16

18 (3)

18 (3)

12

18 (3)

$2 n$ - chromosome numbers determined by direct counting from mitotic cells, followed by the number of plant individuals analyzed in brackets, DNA ploidy level — DNA ploidy level assessed using flow cytometry, with number of diploid $(2 n \sim 2 x)$ and tetraploid $(2 n \sim 4 x)$ plants given. These numbers also correspond to the number of individuals used in morphometric analyses. The localities are given as follows: country (SK - Slovakia, AU - Austria, HU - Hungary), phytogeographical region according to Futák (1984) (for localities in Slovakia), the name of the closest town/village, specification of the locality, altitude, grid map square (according to Niklfeld 1971), collection date, the name of the collector (SŠ - S. Španiel). Chromosome number records labelled with asterisks were taken from Španiel (2007). All other data and ploidy level estimates represent new records. All chromosome numbers were determined by S. Španiel, DNA ploidy levels were assessed by S. Španiel and K. Marhold. Voucher specimens are deposited at SAV. 


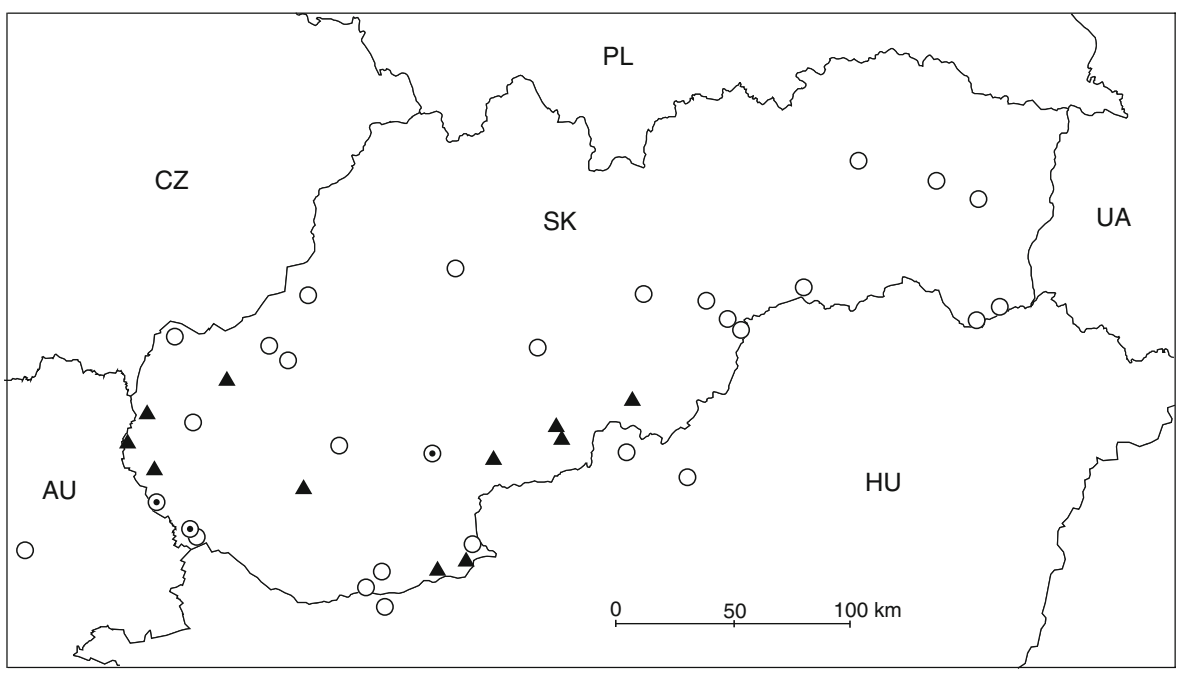

Fig. 1 Sample sites of diploid (empty circles), tetraploid (triangles) and mixed-ploidy (circles with dots) populations of Centaurea stoebe. See Table 1 for details on the localities

originated from type localities of the allegedly diploid $C$. stoebe (=C. stoebe subsp. stoebe; population nr. 13, the locality of the neotype; see Greuter 2003: 56) and the allegedly tetraploid taxon $C$. australis (=C. stoebe subsp. australis; population nr. 17 , one of the three localities mentioned in the protologue). Each population sample consisted of mostly 20-25 plants (see Table 1) bearing both flowers and mature achenes. Before the specimens were dried, three florets per plant were taken from well-developed involucres and attached using adhesive tape to paper to preserve their size and shape. Three mature achenes and three involucral bracts per plant were also attached and used for size measurements (see below). Other achenes collected from the sampled individuals were sown to obtain seedlings and second-generation plants needed for karyological and flow cytometric analyses. The seed offspring was cultivated in the greenhouse and the experimental garden at the Institute of Botany, Slovak Academy of Sciences in Bratislava. The neotype of the name C. stoebe deposited in herbarium $\mathrm{W}$ and two isotypes of the name $C$. australis Pančić ex A. Kern. deposited in the herbarium WU were examined as well (for herbarium acronyms see Holmgren et al. 1990).

\section{Chromosome Counting}

Chromosome numbers were determined in mitotic metaphases of cells from root tips. The root tips were taken from germinating achenes collected in situ from the plants included in morphometric analyses. In one case root tips from a cultivated mature plant of the second generation were also used to confirm the result of flow cytometric analysis (aneuploidy, see below). The root tips were pretreated in $0.002 \mathrm{M}$ aqueous solution of 8-hydroxyquinoline for $4-10 \mathrm{~h}$ at $4{ }^{\circ} \mathrm{C}$, and fixed in a mixture of $96 \%$ ethanol and concentrated acetic acid $(3: 1)$ for $1-24 \mathrm{~h}$ at $4^{\circ} \mathrm{C}$. For maceration a mixture of concentrated hydrochloric acid and $96 \%$ ethanol was used 
(5-10 min). Squashes were made using a cellophane square instead of the cover glass (Murín 1960) and stained in 10\% Giemsa stock solution in Sörensen phosphate buffer for $1 \mathrm{~h}$.

In addition, a survey of chromosome number records published for C. stoebe from Europe was done.

\section{DNA Ploidy Level Estimation}

Flow cytometry was used to estimate ploidy levels of the individuals included in the morphometric analyses. Their DNA ploidy level was, however, assessed indirectly, by measuring nuclear DNA content in plants germinated from the achenes taken from the field-sampled individuals. Leaf samples of one-month-old plants were used. First, samples of plants with known chromosome numbers (both diploid and tetraploid) were analyzed simultaneously with an internal standard (Bellis perennis, $2 \mathrm{C}=3.38 \mathrm{pg}$, Schönswetter et al. 2007), and the ratio of their $\mathrm{G}_{1}$ peak positions was recorded. The DNA ploidy levels of the analyzed plants (of unknown chromosome numbers) were then assessed by their peak position relative to the standard peak. The analyses were performed using the Partec PA II flow cytometer equipped with an HBO-100 mercury arc lamp (Partec GmbH, Germany) at the Institute of Botany, Academy of Sciences of the Czech Republic, Průhonice, Czech Republic.

The DNA ploidy level was estimated on the basis of fluorescence intensity of nuclei stained using the fluorochrome DAPI (4',6-diamidino-2-phenylindole). Tissue from a fresh leaf $\left(0.5 \mathrm{~cm}^{2}\right)$ of the analyzed plant was co-chopped with the standard in a Petri dish with $1 \mathrm{ml}$ of ice-cold Otto I buffer (0.1 M citric acid monohydrate, $0.5 \%$ Tween 20; Otto 1990) using a razor blade. The obtained suspension was filtered through a 42- $\mu \mathrm{m}$ nylon mesh and incubated for at least $5 \mathrm{~min}$ at room temperature. $1 \mathrm{ml}$ of a solution containing Otto II buffer $\left(0.4 \mathrm{M} \mathrm{Na}_{2} \mathrm{HPO}_{4} \cdot 12 \mathrm{H}_{2} \mathrm{O}\right)$, 2-mercaptoethanol $(2 \mu \mathrm{l} / \mathrm{ml})$ and DAPI $(4 \mu \mathrm{g} / \mathrm{ml})$ was added to the flow-through fraction, and stained for 1-2 min. The cytometer was adjusted so that the $G_{1}$ peak of the standard was localized on channel 200. For each measurement, the coefficients of variation $(\mathrm{CV})$ of the standard and the analyzed sample were calculated.

\section{Pollen Grain Size}

Pollen grain size was measured on a representative sample of specimens of both cytotypes (15 plants per ploidy level). The measurements were done to check whether the size of pollen grains is correlated with the ploidy level, and can be used as its indicator. Anthers with pollen were removed from closed capitula before flowering. Pollen grains were released and stained in a drop of acetocarmine jelly (Marks 1954) and measured using an optical microscope. 30 pollen grains per plant were measured and their mean value was used to compare plants of different ploidy levels.

\section{Morphometric Analyses}

Two population samples had to be excluded from morphometric analyses, because they either did not contain enough flowering individuals (population nr. 15) or were damaged 
by grazing and mowing (population nr. 7). Thus, material from 38 localities of altogether 771 plants was subjected to morphological measurements (Table 1) to reveal differences between diploids and tetraploids, or any other morphological variation patterns. Ploidy level was estimated for each examined specimen (indirectly, assessed on the basis of the DNA ploidy level of its seed offspring).

Characters measured or scored are listed in Table 2 and some of them depicted in Fig. 2. They included characters traditionally used for differentiation of the two recognized taxa/cytotypes as can be found in determination keys and floras, as well as several other that appeared as potentially useful for distinction of the two cytotypes. Altogether 15 quantitative characters were measured and four ratios were derived. Florets, bracts and achenes with pappus that were attached to paper were scanned and measured using the software CARNOY (Schols et al. 2002). Mean values from the three measurements (each from another floret/bract/achene attached) per plant were calculated.

Due to logistic reasons, it was not possible to collect all population samples exactly at the same flowering period, which may influence to a certain extent the size of the measured capitula (Španiel, unpubl. data). Still, the characters expressing the size of capitula cannot be excluded from the analyses, as it is reported as one of the most important differential characters among the cytotypes. This fact, however, should be taken into consideration when interpreting the results of the morphometric analyses.

Pearson (parametric) and Spearman (non-parametric) correlation coefficients were computed to reveal pairs of highly correlated characters (Legendre and Legendre 1998).

Table 2 List of characters measured and used in morphometric analyses (see also Fig. 2)

Continuous quantitative characters

LOF length of outer florets from the base to the apex of the longest tip of the floret

LIF length of inner florets from the base to the apex of the corolla tips

LB length of middle involucral bracts

WB width of middle involucral bracts in its widest part

LA length of achenes from the base to the pappus insertion

LP length of pappi

WAP width of appendages of middle involucral bracts excluding lateral fimbriae

LAP length of appendages of middle involucral bracts excluding lateral fimbriae and the apical mucro

LDP length of the dark part of appendages of middle involucral bracts measured as the length between the appendage apex (without apical mucro) and the colour transition (from the black or brown colour of the appendage to the green colour of the bract)

LAM length of apical mucros of appendages of middle involucral bracts from the bifurcation of the uppermost lateral fimbria to the tip of the mucro

LF length of longest lateral fimbria of appendages of middle involucral bracts

Discrete quantitative characters

NS number of stems

NOF number of outer florets in the widest capitulum observed

NIF number of inner florets in the widest capitulum observed

NF number of lateral fimbriae on one side of the appendage of the middle involucral bract (recorded on seven appendages, but with only the largest value taken into consideration), basal membranous colourless fimbriae were excluded 


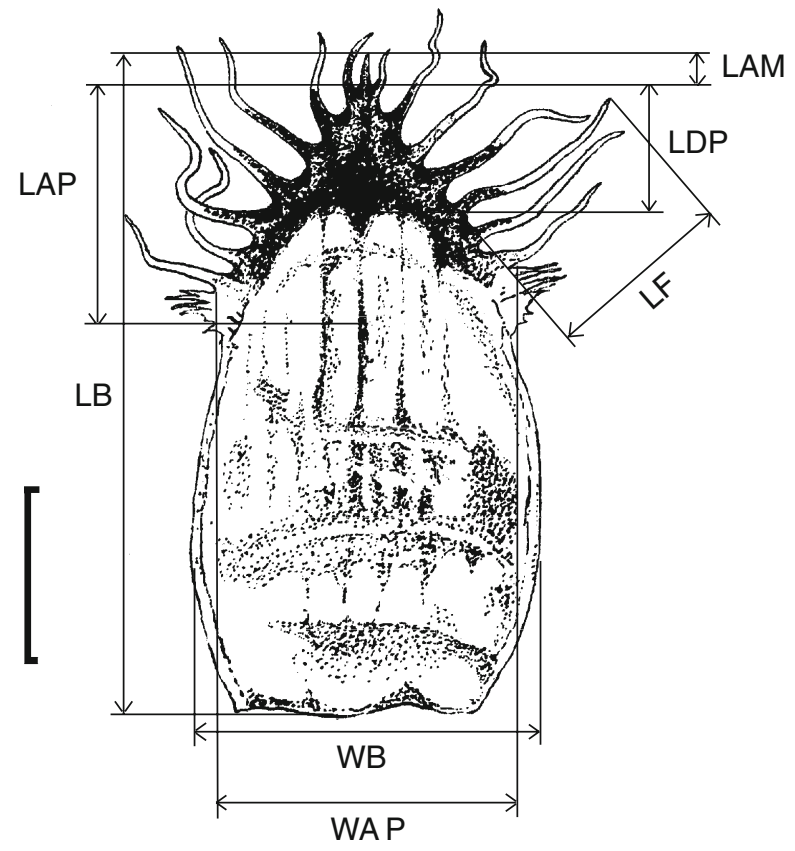

Fig. 2 Middle involucral bract with selected morphological characters included in morphometric analyses: LB - length of middle involucral bract, LAP — length of appendage, WB — width of middle involucral bract, WAP — width of appendage, LAM - length of apical mucro, LDP — length of the dark part of appendage, LF - length of longest lateral fimbria (see Table 2) (drawings by the first author)

Cluster analyses with four different algorithms employed (UPGMA — unweighted pair-group method using arithmetic averages, centroid method — unweighted pair group method using centroids, complete linkage — the furthest neighbour method, Ward method - minimization of the increase of error sum of squares, Everitt 1986) were performed to reveal population clustering. The populations were represented by the mean values of the measured characters. The data were standardized using a zero mean and unit standard deviation, and Euclidean distance was used to compute the secondary matrix. In the case of populations where both diploid and tetraploid plants were found (mixed-ploidy level populations), they were split according to the cytotypes, i.e., the mean values of the characters were computed separately for each cytotype. The (sub)populations were correspondingly denoted as subsample A (for diploids) and subsample B (for tetraploids). The tetraploid plants from the populations nr. 1 and 26, however, were not included in the cluster analyses and the subsequent principal component analysis based on the population means, as the (sub)population mean values of characters might be distorted by the low amount of individuals in these two cases.

Principal component analysis (PCA) (Sneath and Sokal 1973; Krzanowski 1990) was performed based on the correlation matrix of the measured characters. The analysis was run both with individual plants as well as with populations as objects. The method was used to display an overall variation pattern along the first three components extracting most of the original multidimensional character space. 
To examine the extent of morphological separation between the two cytotypes, canonical discriminant analysis was computed (Klecka 1980). This method, in contrast to PCA, maximizes between-group differences. Then, several classificatory discriminant analyses (parametric, non-parametric ones based on probability models, as well as simple linear classification functions) were performed to estimate the percentage of plants correctly assigned to the predetermined groups (ploidy levels), and to find the best discriminant function to assess the ploidy level of a given plant, based on the measured morphological characters. A crossvalidation procedure was used, in which the classification criterion is based on $n-1$ individuals, and then applied for the individual left out. Discriminant analyses generally require multivariate normal distribution of the characters, but were shown to be considerably robust against deviations in this respect (Thorpe 1976; Klecka 1980).

The analyses were run using the software SYN-TAX 2000 for Windows (Podani 2001) and SAS 8.1 statistical package (SAS Institute 2000).

\section{Results}

\section{Chromosome Counting and DNA Ploidy Level Estimation}

Chromosome numbers were determined for 154 plants, and DNA ploidy level was additionally confirmed by flow cytometric analyses for all 771 individuals sampled for the morphometric analyses (Table 1). Out of 40 karyologically studied populations, 26 were diploid $(2 n=18), 11$ were tetraploid $(2 n=36)$, and in three populations both cytotypes were found (mixed-ploidy level populations, see Table 1, Fig. 1). In two of them (populations nr. 1 and 26, Table 1) only three tetraploid individuals were found in each, and the rest of the plants were diploid, while the third population sample (nr. 25) consisted of nine tetraploids and 20 diploids. In many plants B chromosomes (small chromosome fragments) were recorded. Both populations nr. 13 and 17 (type locality of Centaurea stoebe (Mödling) and one of the type localities of C. australis (Bodony), respectively) were proven to be diploid.

The ratio between nuclei fluorescence intensity of $C$. stoebe samples and the internal standard (Bellis perennis) was $0.463-0.497$ (on average 0.475 ) for diploids, and $0.887-0.922$ (on average 0.900 ) for tetraploids (Fig. 3). Coefficient of variation (CV) of the peaks of the standard adjusted at channel 200 ranged from $1.55 \%$ to $2.92 \%$ (on average $2.04 \%$ ), and $\mathrm{CV}$ of peaks of the measured samples varied between $1.78 \%$ and $3.85 \%$ (on average $2.69 \%$ ). One individual with slightly higher relative DNA content than the other diploid plants was observed; two peaks with different fluorescence intensity ratios to the standard, 0.472 (plant of the usual relative DNA content) and 0.529 (plant with the higher relative DNA content), respectively, are apparent in Fig. 3b. This represents a $10.8 \%$ difference in the nuclear DNA content. Direct chromosome counting proved an aneuploid chromosome number with $2 n=19$ for this plant, with one supernumerary chromosome of comparable size. This is a new count and a first evidence of aneuploidy for this taxon. No triploids were found using chromosome counting or flow cytometry. 

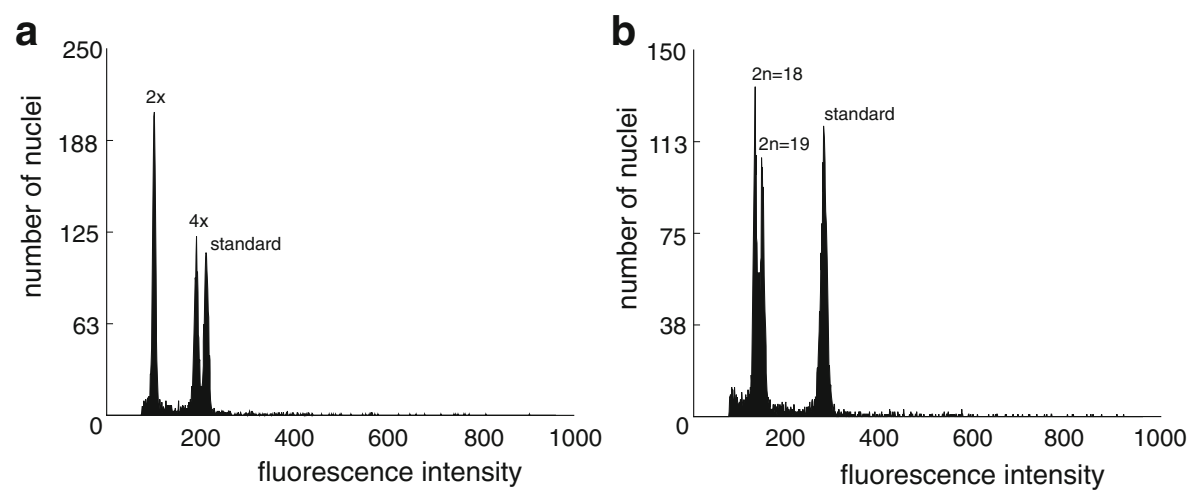

Fig. 3 Flow cytometric histograms of relative nuclear DNA contents obtained from the analyses of DAPIstained nuclei of Centaurea stoebe and the internal standard (Bellis perennis). a Simultaneous analysis of a diploid and a tetraploid plant (both from pop. nr. 25). b Simultaneous analysis of a diploid $(2 n=18)$ and an aneuploid $(2 n=19)$ plant (both from pop. no. 25)

The two cytotypes displayed different distribution patterns in Slovakia. The tetraploid populations were restricted to lowlands or hills of the Podunajská nížina, Ipel'sko-rimavská brázda and Záhorská nížina (with only a scattered extension to the Malé Karpaty Mts.), where they occupy mostly ruderal habitats. The diploids, on the other hand, were found all over Slovakia. In the southwestern part of the country, where their distribution area overlaps with that of the tetraploids, they grow mainly in xerothermic steppe-like habitats (Fig. 1). Nevertheless, the diploids were found also on ruderal sites (populations nr. 3, 15, $20,35,38,39)$ and, conversely, the tetraploids sometimes grow in undisturbed steppe-like habitats (e.g. population nr. 9).

\section{Geographical Distribution of Cytotypes in Europe}

A map showing the distribution of cytotypes of $C$. stoebe in its European area was created based on data from literature (Fig. 4). Details on chromosome counts (localities and references) are presented in an electronic appendix (supplementary information), including the name to which the given count was referred in the original source. The map is based on all previously published chromosome numbers that correspond to $C$. stoebe following the synonymy presented by Ochsmann (2000). Nevertheless, it is possible that in addition to the presented data, at least some records from western Europe published for $C$. paniculata (data neither included in the map nor in the electronic appendix) in fact refer to C. stoebe, as this name was sometimes used for $C$. stoebe and morphologically similar taxa that require further study. Additional tetraploid records for $C$. stoebe were reported from North America (Moore and Frankton 1954; Powell et al. 1974; Taylor and Taylor 1977; Morefield and Schaack 1985; Hill 1995; Ochsmann 1999); one diploid record (under the name C. pseudomaculosa Dobrocz.) is also known from the Russian Far East (Probatova et al. 1996). 


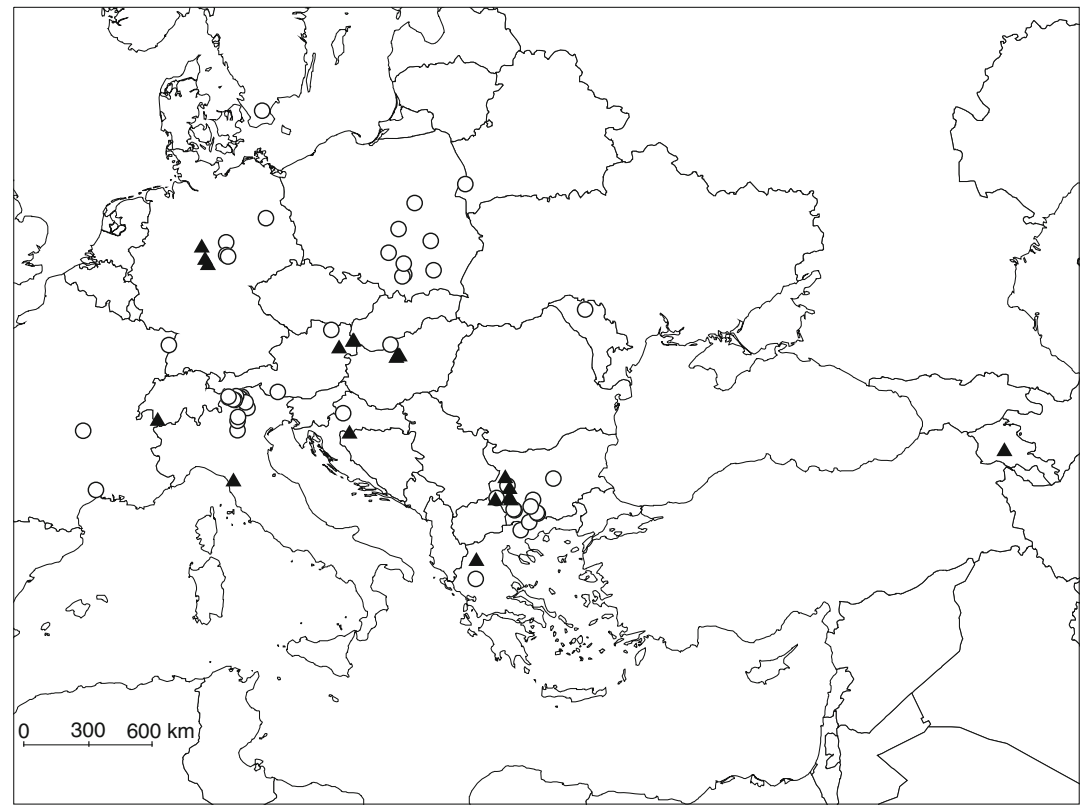

Fig. 4 Geographic distribution of diploids (circles) and tetraploids (triangles) of Centaurea stoebe in Europe based on previously published karyological data (see the electronic appendix for localities and references)

\section{Pollen Grain Size}

Mean pollen grain size (based on 30 measurements per plant) of diploid specimens ranged from 24.8 to $33.6 \mu \mathrm{m}$ (mean value $27.9 \mu \mathrm{m}$ ), that of tetraploid varied between 26.3 and $30.7 \mu \mathrm{m}$ (mean value $28.5 \mu \mathrm{m}$ ). Thus, a broad overlap between the cytotypes was observed, and this character does not allow reliable cytotype identification. This result confirms data published by Ochsmann (2000).

\section{Morphometric Analyses}

Cluster analyses, based on population averages, with four different algorithms employed (UPGMA, centroid method, complete linkage and Ward method) gave slightly different results, nevertheless tetraploid populations tend to cluster together in all cases. Both UPGMA (Fig. 5a) and centroid method (not shown) dendrograms resolved nine tetraploid populations in a single cluster (including, however, one diploid population nr. 35), while the other two tetraploid populations/subsamples (nr. 8 and 25B) were placed in separate positions against all the other populations. The outlying position of population nr. 8 is probably caused by short pappi (LP); the position of subsample nr. 25B could be attributed to a low number of individuals (nine). Diploid population nr. 35 has significantly fewer inner florets (lower NIF values) than the other diploid populations and this is probably why it grouped together with tetraploids. This might be caused also by the later collection date. On the higher level, the tetraploids clustered with diploids from Eastern Slovakia (populations nr. 36-40). In 
a

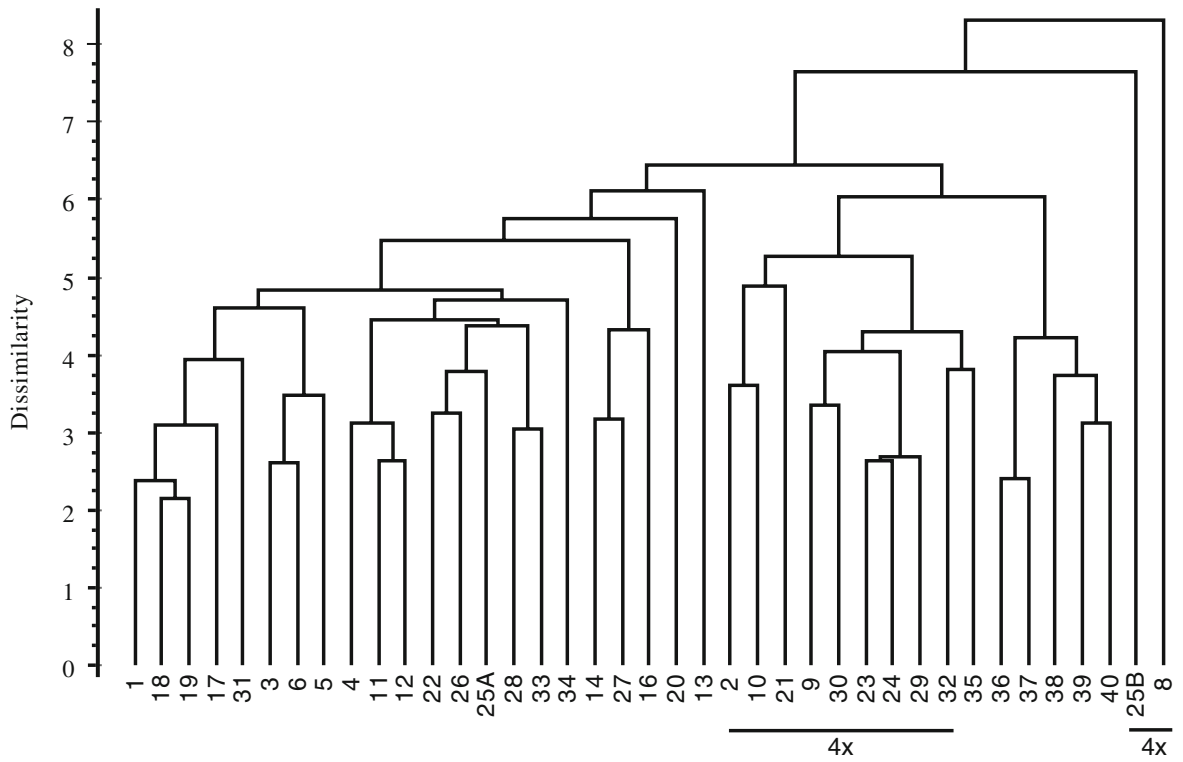

b

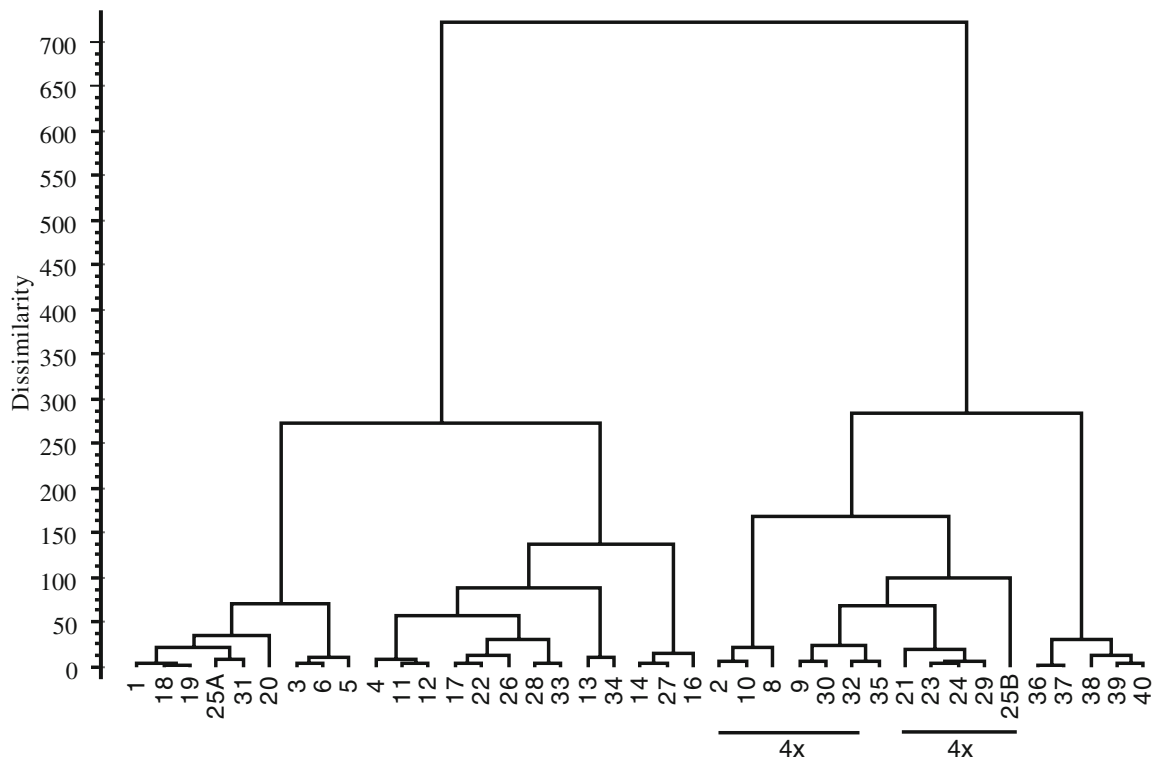

Fig. 5 Cluster analysis of 28 diploid and 11 tetraploid population samples of Centaurea stoebe based on 19 morphological characters. a UPGMA, b Ward method. Populations with the co-occurrence of both cytotypes were split into subsamples denoted as A (diploid plants) and B (tetraploid plants). For localities see Table 1 
the Ward method dendrogram (Fig. 5b) all tetraploid populations clustered together (but again including diploid population nr. 35); this cluster was submersed among the diploid populations. On the higher level, the tetraploids again clustered with the Eastern Slovakian diploids. The complete linkage dendrogram (not shown) showed a clustering pattern different from the other algorithms, with tetraploids placed in two separated clusters (together with population nr. 35), and one tetraploid population sample (nr. 25B) appeared outside all the main clusters. In all cluster analyses, populations nr. 13 and 17 sampled from the type localities of the names C. stoebe and C. australis were placed among the diploid populations.

In the ordination diagram of PCA based on population samples (Fig. 6) diploids and tetraploids formed non-overlapping groupings, with the tetraploids placed in the lower left part of the diagram. Thus, both the first and second component contributed to their differentiation. The diploids were spread along the first component, indicating that the main direction of morphological variation is within the diploids, rather than between the cytotypes. Diploid populations from Eastern Slovakia (populations nr. 36-40) were shifted to the left side of the diagram, pointing to a certain geographic pattern. Diploid population nr. 35 was resolved in the position close to the tetraploids, in accordance with the cluster analyses, but not directly placed among them. Characters with the highest correlations (based on eigenvector values, Table 3) with the first axis were the length of middle involucral bracts (LB), their appendages (LAP), the length of the dark part of appendages (LDP), and the length of the lateral fimbria (LF). Those mostly correlated with the second axis were the ratio of length of pappi and achenes (LP/LA), number of stems (NS), and length of pappi (LP).

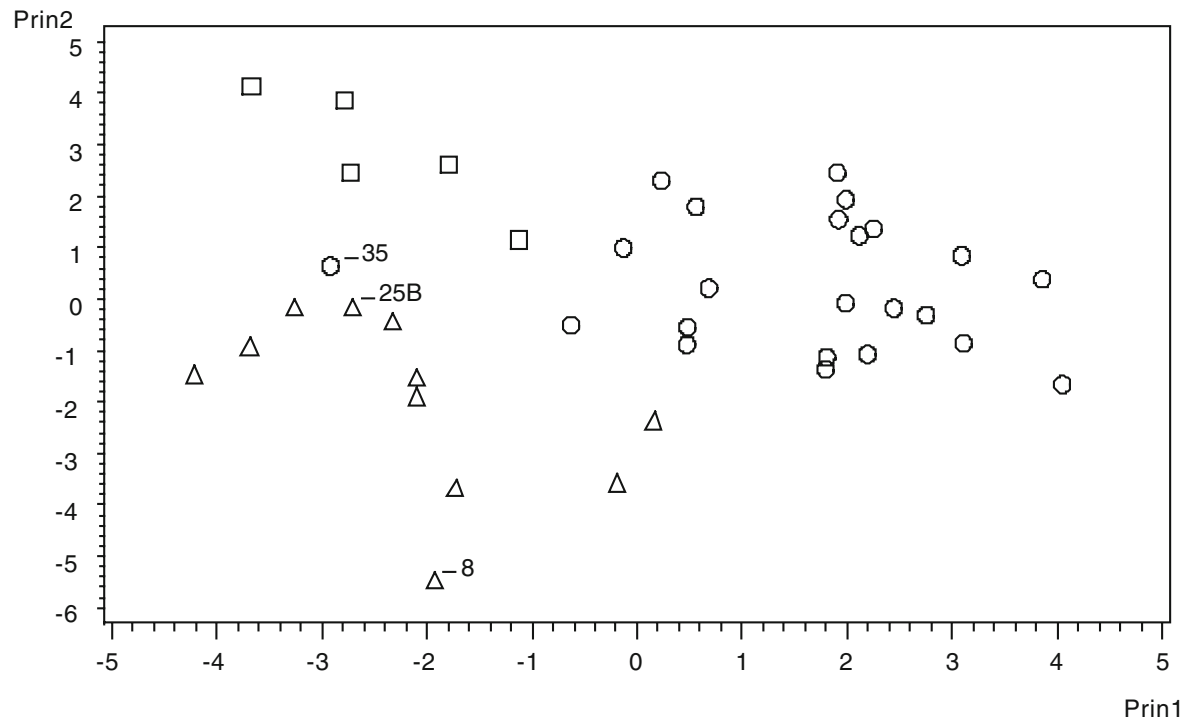

Fig. 6 Ordination graph of principal component analysis of 39 population samples of Centaurea stoebe based on 19 morphological characters. First two components explain $30 \%$ and $21 \%$ of variation, respectively. Circles and squares - diploid populations (squares representing populations nr. 36-40); triangles - tetraploid populations. Populations with the co-occurrence of both cytotypes were split into two subsamples, marked here according to their ploidy level. Positions of the populations/subsamples discussed in the text are highlighted 
Table 3 Results of morphometric analyses of Centaurea stoebe

\begin{tabular}{|c|c|c|c|c|c|}
\hline & \multicolumn{2}{|l|}{ PCA1 } & \multicolumn{2}{|l|}{ PCA2 } & \multirow{2}{*}{$\frac{\mathrm{CDA}}{\mathrm{Can} 1}$} \\
\hline & Prin 1 & Prin2 & Prin 1 & Prin2 & \\
\hline LOF & -0.038 & 0.064 & 0.094 & 0.097 & 0.102 \\
\hline LIF & -0.014 & 0.038 & 0.134 & 0.082 & -0.032 \\
\hline LB & 0.300 & -0.186 & 0.370 & -0.102 & -0.015 \\
\hline WB & 0.288 & -0.036 & 0.305 & 0.119 & 0.167 \\
\hline LA & -0.071 & -0.148 & 0.040 & -0.057 & -0.176 \\
\hline LP & 0.162 & 0.383 & 0.112 & 0.470 & 0.510 \\
\hline WAP & 0.286 & -0.178 & 0.350 & 0.015 & 0.105 \\
\hline LAP & 0.306 & -0.309 & 0.397 & -0.208 & 0.025 \\
\hline LDP & 0.304 & -0.288 & 0.364 & -0.266 & 0.096 \\
\hline LAM & 0.111 & 0.062 & 0.143 & 0.065 & 0.131 \\
\hline LF & 0.379 & 0.044 & 0.341 & 0.029 & 0.543 \\
\hline NS & -0.103 & -0.362 & -0.017 & -0.207 & -0.500 \\
\hline NOF & 0.273 & 0.282 & 0.132 & 0.244 & 0.567 \\
\hline NIF & 0.309 & 0.230 & 0.196 & 0.261 & 0.642 \\
\hline $\mathrm{NF}$ & 0.328 & 0.098 & 0.267 & 0.134 & 0.542 \\
\hline WAP/LAP & -0.167 & 0.288 & -0.178 & 0.296 & 0.062 \\
\hline LAP/LDP & -0.135 & -0.085 & -0.083 & 0.167 & -0.144 \\
\hline LP/LA & 0.168 & 0.400 & 0.100 & 0.486 & left out \\
\hline $\mathrm{LB} / \mathrm{WB}$ & 0.082 & -0.225 & 0.067 & -0.275 & -0.228 \\
\hline
\end{tabular}

PCA1 - eigenvectors expressing correlations of the measured characters with the principal component axes of PCA based on 39 population samples (see Fig. 6), PCA2 - eigenvectors expressing correlations of the measured characters with the principal component axes of PCA based on 771 individual plants (see Fig. 7), CDA - total canonical structure expressing correlations of the measured characters with the canonical axis (see Fig. 8). For character explanations see Table 2.

PCA based on individuals as objects showed an extensive overlap between diploid and tetraploid plants. Only a slight tendency along the second axis was visible, with tetraploids shifted to the lower side, and diploids to the upper side of the ordination diagram (Fig. 7). This shift is attributed to the ratio of length of pappi and achenes (LP/LA) and length of pappi (LP) that are most correlated with the second axis (Table 3). Similarly, a slight shift of the Eastern Slovakian diploid populations towards the left side of the diagram is visible, correlated with the same characters as in the PCA based on populations. There is no apparent differentiation along the third principal component (not shown).

Based on Spearman and Pearson correlation coefficients, strong correlation (0.95) between two characters, LP/LA and LP, was revealed. Thus, one of these characters (LP/LA) was excluded from the subsequent discriminant analyses.

Canonical discriminant analysis based on individual plants and with the cytotypes defined as two groups showed only weak separation between the groups (Fig. 8). Characters exhibiting the highest correlations with the canonical axis were the number of inner florets (NIF), number of outer florets (NOF), number of fimbriae (NF), length of fimbriae (LF) and length of pappi (LP) (Table 3). In contrast to the canonical discriminant analysis, in the non-parametric (k-nearest neighbours) classificatory discriminant analysis based on probability models, a high number of plants were correctly assigned to the corresponding ploidy level $(89.6 \%$ of diploids and $91.7 \%$ of tetraploids). The parametric method based on probability models and 


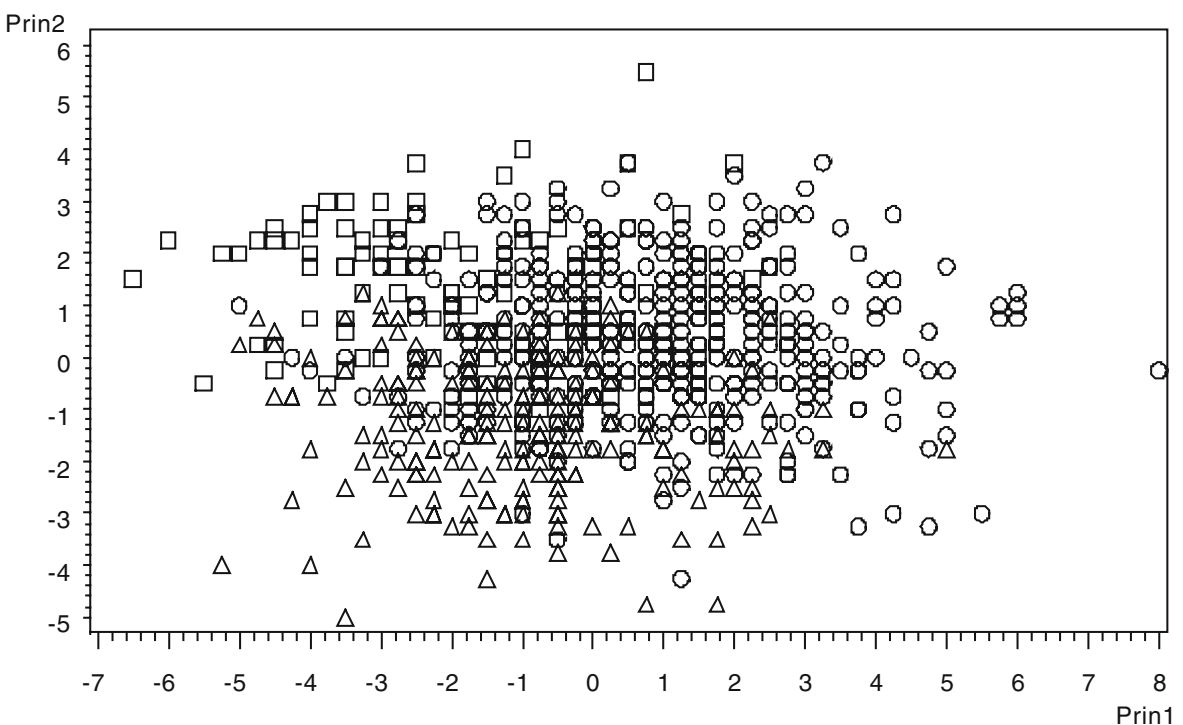

Fig. 7 Ordination graph of principal component analysis of 771 individuals of Centaurea stoebe based on 19 morphological characters. First two components explain $24.6 \%$ and $13.7 \%$ of variation, respectively. Circles and squares — diploid populations (squares representing populations nr. 36-40); triangles tetraploid populations

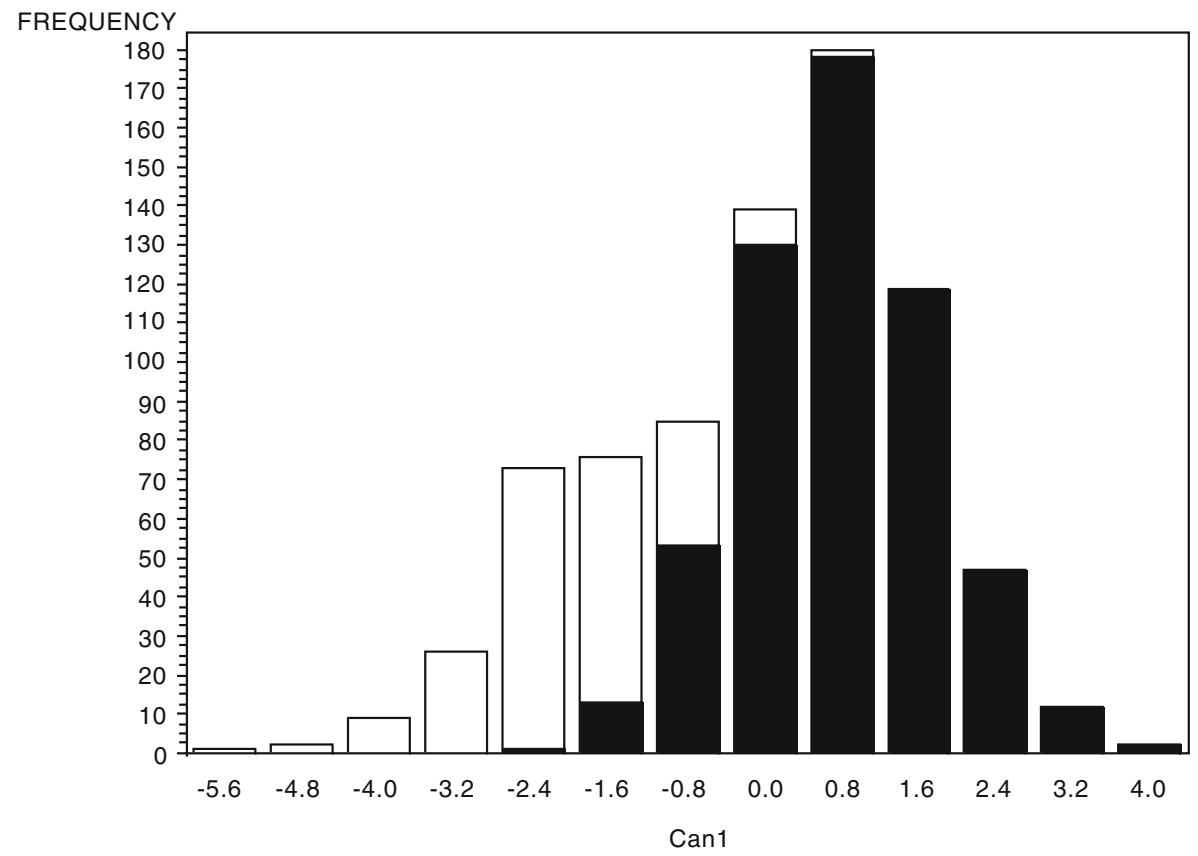

Fig. 8 Histogram of canonical discriminant analysis of diploid (black) and tetraploid (white) individuals of Centaurea stoebe based on 18 morphological characters 
employing quadratic discriminant functions resulted in similar estimates (correct identification of $93.3 \%$ of diploids and $83.8 \%$ of tetraploids). To acquire a simple classification criterion that could be used for the identification of a particular cytotype, linear classification functions were derived using parametric discriminant analysis. The following classification functions were obtained; for diploids it reads

$$
\begin{aligned}
f(x)= & -6692+L O F * 0.55108+L I F^{*} 2.96-L B^{*} 1941+W B^{*} 4333+L A * 33.88835 \\
& -L P * 8.54382-W A P^{*} 887.43581+L A P^{*} 717.33746+L D P^{*} 582.54058 \\
& -L A M * 24.19057+L F^{*} 15.92521+N S^{*} 2.27415+N O F^{*} 1.71255+N I F^{*} 0.63087 \\
& +N F^{*} 5.96914+W A P / L A P^{*} 1377+L A P / L D P * 334.68533+L B / W B * 4858 ;
\end{aligned}
$$

for tetraploids

$$
\begin{aligned}
f(x)= & -6697+L O F * 0.37993+L I F * 3.53432-L B * 1942+W B * 4337+L A * 35.92146 \\
& -L P * 11.76189-W A P * 883.91523+L A P * 720.26897+L D P^{*} 578.52693 \\
& -L A M * 24.81214+L F * 9.01356+N S * 2.72617+N O F * 1.36546+N I F * 0.51881 \\
& +N F * 4.67825+W A P / L A P * 1375+L A P / L D P * 334.20604+L B / W B * 4865 .
\end{aligned}
$$

These functions can be used to estimate the ploidy level of an unknown individual. It is necessary to measure characters with the accuracy of one decimal position, in units as given in Table 2, and to insert their values in both formulas. Scores for each function are computed, compared, and the plant individual is classified into the group (ploidy level) that shows the higher score. When the same dataset as used in discriminant analyses based on probability models (see above) was tested using these two functions, $97.66 \%$ of diploids but only $77.31 \%$ of tetraploids were correctly assigned to the cytotypes.

To assess the reliability of the correct ploidy level assignment for plants of unknown ploidy level by another procedure, 41 parametric classificatory discriminant analyses were performed, based on probability models. In each case, a classificatory criterion was derived from individuals from $n-1$ populations ("training data set"), and then applied for the individuals from the population left out ("population of unknown ploidy level"). In this procedure, correct ploidy level assignment varied from $63.6 \%$ to $100 \%$ (on average $91.1 \%$ ) for diploids, and from $47.8 \%$ to $100 \%$ (on average $78.8 \%$ ) for tetraploids. The lowest values, below $70 \%$, were observed in diploid subsample nr. 26A and tetraploid populations/subsamples nr. 1B, 10, 21, 29 and 32 .

Figure 9 compares variation in selected morphological characters of diploid and tetraploid plants. Only the characters with the highest contributions to the separation or shift between the cytotypes, as revealed by PCA and CDA, are presented. Considerable overlap in their values is apparent, and it is evident that none of them allows reliable determination of the ploidy level.

\section{Nomenclature}

There are two names, which are currently used for the Central European plants of $C$. stoebe in its wider sense, namely $C$. stoebe L. subsp. stoebe and C. stoebe subsp. australis (Pančić ex A. Kern.) Greuter (based on C. australis Pančić ex A. Kern.). 
a

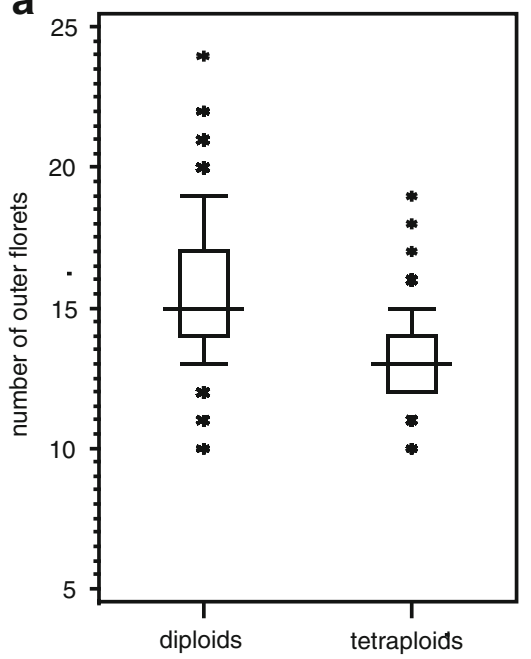

C

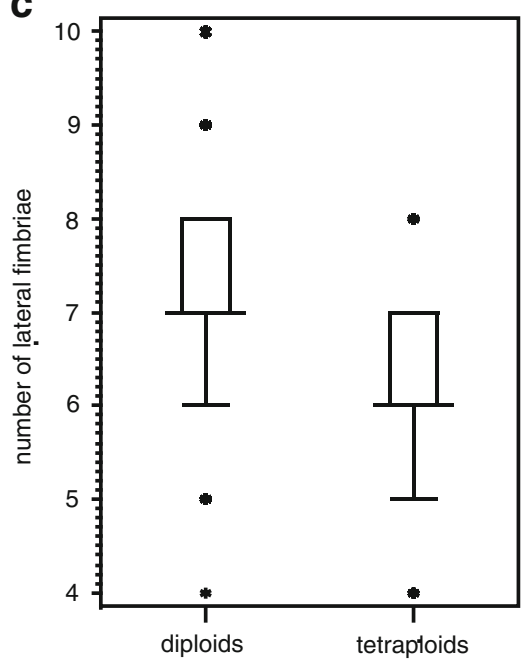

b

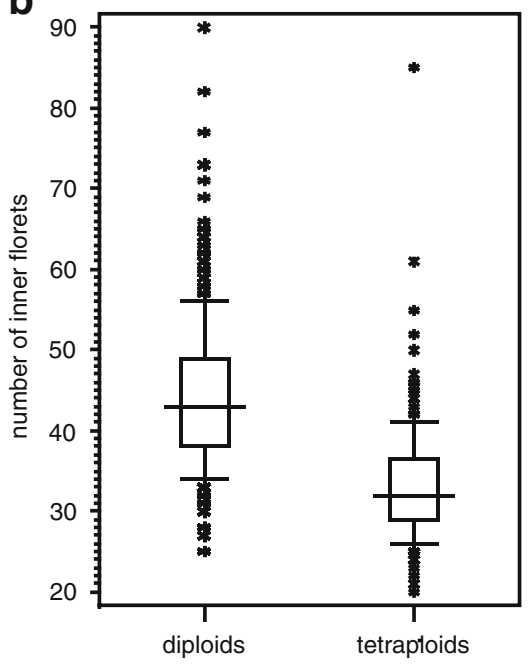

d

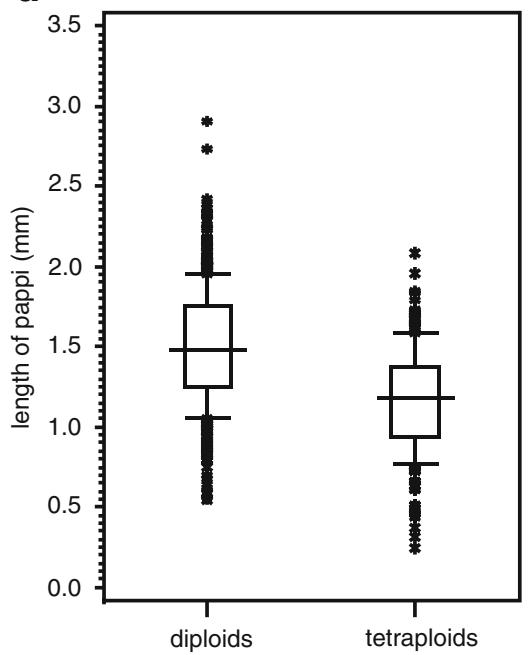

Fig. 9 Variation in selected morphological characters of 555 diploid and 216 tetraploid individuals of Centaurea stoebe. Rectangles define the 25th and 75th percentiles; horizontal lines show median; whiskers are from the 10th to 90th percentiles; asterisks show extreme values. a number of outer florets, b number of inner florets, $\mathbf{c}$ number of lateral fimbriae, $\mathbf{d}$ length of pappi

As no specimen used by Linnaeus to describe $C$. stoebe is known to exist nor is there a reference to an illustration in the protologue, Greuter (2003: 56) selected the following neotype for this name: "Centaurea rhenana Bor., Niederösterreich, Felsen in der Mödlinger Klause" (13 Jul 1908, Korb, W). Examination of the neotype showed that especially according to the width of capitula and the presence of a single stem it is very likely that it is diploid.

Kerner (1872) mentioned in the protologue three localities of his C. australis: “... In mittelungar. Berglande auf dem Czigléd bei Erlau [Eger, Hungary]; in der Matra 
bei Bodony [Hungary]; in der Pilisgruppe auf dem Blocksberge bei Ofen [Buda, city quarter of Budapest, Hungary]...". There are two relevant specimens in Kerner's herbarium deposited in WU, which can be considered as syntypes: $i$ ) "E flora hungar. Comit. Heves, Centaurea maculosa Lam., [revised as] Centaurea australis Pančic?, In Matra ad pagum Bodony" (17 Sept 1867, [M.] Vrabélyi, WU-Kerner 034331); ii) "E flora hungar. Comit. Heves, Centaurea australis Pančic, Inter vineas collis Czigléd territorii Agriensis" (18 Oct 1867, [M.] Vrabélyi, WU-Kerner 034330). Considering the width of capitula in particular, it is very likely that the specimen from Bodony is a diploid, while the one from the vineyards Czigléd near Eger is a tetraploid. There is no specimen from Buda in Kerner's herbarium, which may belong to the original material of the name C. australis.

\section{Discussion}

\section{Chromosome Counts and DNA Ploidy Level Estimation}

In accordance with previous chromosome number records from Europe (see the electronic appendix for literature survey), we here confirmed the presence of two cytotypes within Centaurea stoebe. Together with the data presented in Španiel (2007) listed also here (see Table 1) we provided a fairly good overview of cytotype distribution in Slovakia (Fig. 1). Diploid populations are more common than tetraploid ones, which corresponds to the pattern seen also on the European scale (see Fig. 4). Mixed-ploidy level populations, providing thorough population-level screening, can also be found.

Besides the previously known diploid and tetraploid chromosome numbers, an aneuploid number with $2 n=19$ (i.e., with one supernumerary chromosome) was found in a single plant from population nr. 25 (see Table 1, Fig. 3b). Aneuploidy has not been observed yet in $C$. stoebe, and it seems to be rare in the whole genus Centaurea (Goldblatt and Johnson 2007). The only aneuploid counts reported within Centaurea are probably those determined in C. monticola $(2 n=19$ and $2 n=20)$ and C. paniculata $(2 n=19)$. In $C$. monticola a few aneuploid plants besides regular diploid ones $(2 n=18)$ were observed in two populations (Blanca López 1983), in $C$. paniculata the aneuploid number of chromosomes probably occur regularly in var. esterelensis Burn. (Guinochet 1956). B chromosomes were found in most populations studied here. Their occurrence within C. stoebe is common (Skalińska et al. 1959; Löve and Löve 1961b; Agapova et al. 1990; Lövkvist and Hultgård 1999; Ochsmann 1999, 2000). No triploids were found, which could indicate hybridization between diploids and tetraploids, and no such plants were reported in literature either.

Although the DAPI (A-T selective) fluorescence intensity is not appropriate for the measurements of the genome size, we observed that the fluorescence intensity (the relative nuclear DNA content) in tetraploids was less than twice as high as in diploids. This indicates that the genome size of tetraploids is less than double that of diploids. This coincides with the findings by Bancheva and Greilhuber (2006), who determined monoploid genome size of diploids and tetraploids of $C$. stoebe from Bulgaria as $0.883 \mathrm{pg}$ and from Austria as $0.79 \mathrm{pg}$. Similarly, a decrease in the 
nuclear DNA content in tetraploids when compared to the diploids is known also in other species of the genus Centaurea (Siljak-Yakovlev et al. 2005; Bancheva and Greilhuber 2006). Also more generally, additivity in genome size of polyploids relative to diploid progenitors can be expected, but does not always occur. Genome size contraction (i.e., genome size decrease) following polyploidization has been reported rather frequently, and appears to be more common than the opposite process, i.e., genome expansion (see Wendel et al. 2002; Leitch and Bennett 2004).

\section{Morphological Differentiation Between the Cytotypes}

As for morphological differentiation between the two cytotypes, which is the major focus of this study, the results appear to be equivocal, indicating that the morphological distinction is rather subtle and difficult to extract. Whereas morphological tendencies towards the cytotype separation are evident at the population level, these differences are substantially blurred at the level of individual plants. The PCA (Fig. 6) computed on population averages resulted in a fairly good cytotype separation. Similarly, diploid and tetraploid populations each tended to group together in the cluster analyses (Fig. 5), indicating that morphological differentiation between the cytotypes does exist. Nevertheless, clustering patterns differed among the dendrograms produced by different algorithms, not only in terminal branches but also in the major clusters (compare Fig. 5a and b), suggesting that the differentiation is not very strong and that there is considerable amount of variation also within the cytotypes. This is seen, e.g. in the slight differentiation of the Eastern Slovakian diploids, which show differences in the length of middle bracts, their appendages and related characters. In the PCA based on individual plants as objects (Fig. 7) diploid and tetraploid plants were considerably intermingled, and also differentiation within the diploids is largely blurred. Neither CDA that weights characters to stress the between-group variation component yielded a satisfactory degree of differentiation between the cytotypes. Similar cases, where morphological differentiation or at least tendencies among different cytotypes were inferred at the level of populations, but failed to distinguish them at the level of individuals, were reported also in other plant groups (e.g. Senecio jacobea, Hodálová et al. 2007; Cardamine pratensis, Lihová et al. 2003; Marhold 1996).

Here we also explored the potential and strengths of classificatory discriminant analyses for cytotype identification, and how these can be of use in practice. Both non-parametric and parametric classificatory discriminant analyses based on probability models resulted in a high accuracy of cytotype identification $(89.6 \%$ $-93.3 \%$ ), but neither simple linear identification functions nor the approach that assesses the ploidy level of an "unknown" population based on the "training" dataset using the statistical software as specified above yielded results of such high accuracy. Nevertheless, ploidy level of a given plant can be at least assessed with a certain error rate (see Results), bearing in mind also its asymmetry (less reliable identification of tetraploids). This also means that plants of "typical" phenotypes for the particular cytotype (those placed in the ordination space with little cytotype overlap) can be identified using this approach with reasonable accuracy. Similar identification approaches based on the classification functions were also presented, e.g. in the identification key to Betula pendula and B. pubescens (Atkinson and 
Codling 1986, adopted also by Stace 1991) or used for cytotype identification in Oxycoccus palustris (Suda 1998).

In previous identification keys, floras and other taxonomic works (e.g. Dostál and Červenka 1992; Adler et al. 1994; Ochsmann 2000; Simon 2000) the distinction between the two taxa/cytotypes of $C$. stoebe was based on characters such as the length and width of capitula, length of the apical mucros of the appendages of the involucral bracts, the ratio of the length of pappi and achenes, and the number of lateral fimbriae. Indeed, the ratio length of pappi/achenes, the number of lateral fimbriae, as well as the size of capitulum (here, however, expressed by the number of florets, a character not biased by the herbarium specimen pressing) were confirmed by our study as the characters that best differentiated between the cytotypes (both in PCA and CDA). Nevertheless, analyses performed at the level of individual plants showed a considerable overlap between diploids and tetraploids in these characters (see Fig. 9). It should be noted that the length of pappi/achenes ratio is strongly correlated with the length of pappi. The length of achenes appears to be rather constant, and thus the length of pappi is sufficient to record, containing the same information as the ratio. The length of the apical mucros of the appendages of the involucral bracts, often reported as a diagnostic character as well, was not confirmed in our study. We should also consider seasonal variation in the size (mainly width) of capitula, because capitula at the beginning of flowering seem to be usually larger (Španiel, personal observation). Plant material used in the present study was collected in later flowering stages (to obtain also mature seeds from the same individuals), and this may have somewhat influenced the variation range seen.

In this study, emphasis was put on quantitative morphological characters measured on capitula; other, mainly vegetative characters (e.g. morphology of basal and stem leaves) show too much variation within populations to be considered (Španiel, personal observation), and basal leaves are already withered at the flowering stage.

Ochsmann (2000) stressed that diploids of C. stoebe are monocarpic, while tetraploids are polycarpic. Several papers (Boggs and Story 1987; Story et al. 2001) reported also on the life cycles of the North American tetraploids, confirming their polycarpism. Monocarpic plants of $C$. stoebe develop a leaf rosette in the first year, and overwinter in this stage. One or (rarely) more stems bearing inflorescences are developed in the second year, and the plant finally dies. Polycarpic plants can live and flower up to nine years (Boggs and Story 1987). After the first flowering and in all subsequent years, new leaf rosettes are developed at the base of the previous yearrosette. Thus, the total number of rosettes and stems of a polycarpic plant increases each year.

Although no long-term cultivation experiments that would enable comparison of a representative number of plants of both cytotypes of $C$. stoebe have been carried out in the present study, and no conclusive results can therefore be reported, our observations (Španiel at al., unpubl.) seem to confirm the above-mentioned pattern. Diploid populations indeed appeared to be monocarpic, although individuals bearing more stems that could indicate polycarpism were exceptionally found as well. In tetraploid populations, however, many old, obviously polycarpic individuals possessing several independent basal parts/rosettes were often found. This trait 
may thus help distinguish the cytotypes, especially the tetraploid populations, but it should be noted that there is no distinction seen in the first year of flowering.

\section{Ecological Differentiation Between the Cytotypes}

Ochsmann (2000) suggested that tetraploids of $C$. stoebe occur more frequently in man-made ruderal habitats than diploids. Our observations, however, showed that the association of the cytotypes with a particular type of habitat may not be so strong. Nevertheless, prevalence of the diploids in the area studied (see Fig. 1) and their presence at localities with harsher climate, compared to the tetraploids, suggest their broader ecological amplitude. Similar observations, where a broader ecological niche was found for one cytotype than for the other, were recently reported in Senecio carniolicus (Schönswetter et al. 2007). To understand the ecological differentiation of the cytotypes in $C$. stoebe, definitely a more detailed ecologyoriented study is needed.

That only tetraploids of $C$. stoebe established in North America (Moore and Frankton 1954; Morefield and Schaack 1985; Hill 1995; Ochsmann 1999; Powell et al. 1974) is rather intriguing; it might be a stochastic feature or an indication for their ecological differentiation and thus different success in establishment and spread into a newly invaded area. The recent study comparing cpDNA haplotype diversity of $C$. stoebe in Europe and North America (Hufbauer and Sforza 2008) indicated multiple introductions into North America. Because diploids are at least as common as tetraploids in Europe, the absence of diploids in North America does not seem to be just due to stochastic processes. Recently a climatic niche shift between the native (European) and invaded (North American) area of $C$. stoebe was proved (Broennimann et al. 2007), but diploids and tetraploids were dealt with as one entity in that study, thus no comparisons between the cytotypes were possible.

\section{Origin of Mixed-ploidy Level Populations}

The co-occurrence, frequency distribution and the origins of infraspecific cytotypes are challenging topics, but they have not yet been well explored (Halverson et al. 2008). Recent studies have indicated that co-distribution of cytotypes can be more widespread than expected. This refers not only to the cytotype variation among but also within populations (see e.g., Schönswetter et al. 2007; Suda et al. 2007; Halverson et al. 2008). Although the presence of mixed-ploidy level populations within $C$. stoebe has not been documented so far, here we found three such populations. Definitely, intensive intra-population screening is needed to document such cases. According to theoretical predictions, the co-occurrence of different cytotypes should be unstable, with minority cytotypes exposed to the frequencydependent elimination process, unless niche differentiation or strong pre-zygotic isolation between the cytotypes exist (Levin 1975; Van Dijk and Bakx-Schotman 1997; Husband 2000; but see Halverson et al. 2008). In two of the sampled mixedcytotype populations the tetraploids were indeed rare, but in the third one as many as nine tetraploid individuals were detected out of all 29 sampled ones.

Ochsmann (2000) hypothesized that tetraploids of $C$. stoebe arose only once, presumably in the southeastern part of the species area, and subsequently colonized 
the present range. Nevertheless, the distribution ranges of diploid and tetraploid populations largely overlap both at the European and more regional scales (see Figs. 1, 4), and mixed-ploidy level populations with lower frequency of tetraploids can be found. This may suggest that even if most of the distribution range of the tetraploids arose by colonization of the well-established and stabilized tetraploids from a single centre, the repeated origin of tetraploids within diploid populations and their establishment under favorable conditions is also possible, and may have contributed to the present-day distribution patterns.

Present data do not allow conclusive answers in this respect. Molecular markers coupled with detailed studies of population dynamics in mixed-ploidy level populations including the evaluation of the relative fitness of cytotypes and the assessment of the production of unreduced gametes are inevitable (Husband and Sabara 2003; Husband 2004).

\section{Taxonomic Treatment of Different Cytotypes}

Several central European authors have treated the two cytotypes of $C$. stoebe as separate taxa, either at the species or subspecies level (e.g. Soó 1970; Mądalski and Ciaciura 1972; Schubert and Vent 1976; Dostál and Červenka 1992; Ochsmann 2000). The results presented in this paper, mainly equivocal morphological distinction between the cytotypes, largely sympatric distribution, and the occurrence of mixedcytotype populations, are arguments against such taxonomic treatment. However, (weak but obvious) tendencies in morphological differentiation mainly at the population level, differences in life-history traits, and indications for ecological differentiation (to be explored in more details) might support their formal taxonomic recognition. At the current stage of knowledge on $C$. stoebe, however, we adhere to a taxonomic concept of a single species without recognizing the cytotypes as separate taxa (species or subspecies), in accordance with the recent treatments by Štepánek (2002) and Štepánek and Koutecký (2005). Generally, there is no consensus on the questions of taxonomic treatments of taxa including multiple cytotypes in recent literature, but autopolyploids have traditionally been considered conspecific - mostly just as cytotypes of a single species, without recognition of intraspecific units. This fact has been pointed out in the recent review by Soltis et al. (2007), who focused on the taxonomic significance of autopolyploidy and argued for accepting it as a significant mechanism of speciation. They stressed that even if morphological variation does not allow reliable cytotype identification, they should be considered as distinct species on the basis of geographical and ecological differences and reproductive isolation (meeting the criteria of multiple species concepts), because of their evolutionary significance and for practical reasons (e.g. conservation of rare cytotypes). Rowley (2007), however, contradicted their arguments and argued for a more flexible approach in taxonomic classification, employing also infraspecific categories.

Our taxonomic decision relies also on numerous other cases documenting the presence of intraspecific cytotypes with similar variation patterns. Within the related species Centaurea phrygia, two cytotypes were reported, differing slightly in morphology and geographically differentiated, nevertheless they were not taxonomically classified (Koutecký 2007); similarly diploids and tetraploids remained unclassified in $C$. jacea subsp. nigra based on the detailed morphometric study 
(Vanderhoeven at al. 2002). In Senecio jacobaea subsp. jacobaea where only minor morphological differences between tetraploids and octoploids at the level of populations were found, cytotypes were not taxonomically classified either, also because of the lack of geographical or ecological differentiation (Hodálová et al. 2007). Similar taxonomic conclusions when cytotypes remained unclassified because of insufficient differentiation in morphology, ecology, phenology and/or distribution were adopted, e.g. in Pseudolysimachion maritimum (Trávníček et al. 2004), Parasenecio auriculata var. kamtschatica (Nakagawa 2006), Vaccinium microcarpum (Suda 1998; Suda and Lysák 2001), Andropogon gerardii (Keeler and Davis 1999), Cardamine pratensis, C. raphanifolia, and C. gallaecica (Lihová et al. 2003; Perný et al. 2005). However, Central European tetraploids of Cardamine amara are, despite only minor morphological differences, treated as a distinct subspecies (subsp. austriaca), stressing its mainly allopatric distribution and a unique evolutionary history (Marhold 1999; Lihová et al. 2000, 2004).

\section{Nomenclature}

The karyological analysis of plants from the single type locality of C. stoebe (Mödling, population nr. 13) revealed only diploids, and also judging from the morphology of the type specimen, it is beyond any doubt that the name $C$. stoebe refers to the diploids. The application of the name $C$. australis (or C. stoebe subsp. australis), however, depends on the choice of the lectotype from the available syntypes. The original material of this name, represented by two syntypes, seems to include both diploids and tetraploids. While diploids were confirmed at the locality near Bodony (Hungary; here the studied pop. nr. 13), morphology of the specimen from another locality, the vineyards Czigléd near Eger, suggests a tetraploid level, but it needs to be confirmed either by chromosome counting or by flow cytometric estimates. This is mainly why we still hesitate to select the lectotype of this name. Although of no nomenclatural relevance, it is worth mentioning that at the third locality mentioned in the protologue of $C$. australis, for which there is no relevant specimen in Kerner's herbarium in WU (Buda, city quarter in Budapest), tetraploids were reported by Ochsmann (1999).

\section{Concluding Remarks}

The genus Centaurea comprises several polyploid complexes that have been recently studied or are subject of ongoing research. These include the Centaurea phrygia group (Koutecký 2007), C. jacea group (Hardy et al. 2000, 2001; Vanderhoeven et al. 2002; Koutecký 2008), and also C. stoebe (Hufbauer and Sforza 2008; current study; Mráz et al. in prep.). Results based on a wide spectrum of applied methods, including morphometric, karyological and molecular analyses, will give the possibility of deeper insights into speciation patterns in this genus, into auto- $v s$ allopolyploidy, and morphological differentiation among ploidy levels. Our study indicates that the observed patterns are not straightforward. The morphological differences apparent at the population level are blurred at the level of individual plants, and also populations with the co-occurrence of different cytotypes can be found. This stresses the need for further complex studies in wider distribution areas, including detailed population 
screening for diploids and tetraploids, as well as the use of morphometric and molecular methods. Evolutionary implication of the invasive tetraploid populations from North America should be explored in detail as well.

Acknowledgements This study was financially supported by the Slovak Research and Development Agency, Bratislava, Slovakia (grant no. APVT-51-026404) and by the Ministry of Education, Youth and Sports of the Czech Republic (grant no. 0021620828). We are grateful to Walter Till (Institute of Botany, University of Vienna) for his kind help in searching for the original material of Centaurea australis in the herbarium WU, and to Norbert Riezing (Környe, Hungary) for the company during the fieldwork in Hungary. P. Trávníček (Institute of Botany, Academy of Sciences of the Czech Republic, Průhonice) assisted us with flow cytometric analyses.

\section{References}

Adler W, Oswald K, Fischer R (1994) Exkursionsflora von Österreich. Eugen Ulmer, Stuttgart

Agapova ND, Arkharova KB, Vakhtina LI, Zemskova EA, Tarvis LV (1990) Chisla khromosom tsvetkovykh rastenii flory SSSR: Aceraceae - Menyanthaceae. Nauka, Leningrad

Atkinson MD, Codling AN (1986) A reliable method for distinguishing between Betula pendula and $B$. pubescens. Watsonia 16:75-76

Baksay L (1958) The chromosome numbers of Ponto-Mediterranean plant species. Ann Hist-Nat Mus Natl Hung 50 (Ser Nov 9):121-125

Bancheva S, Greilhuber J (2006) Genome size in Bulgarian Centaurea s. 1. (Asteraceae). Pl Syst Evol 257:95-117

Blanca López G (1983) Números cromosomáticos de plantas occidentales. Ann Jard Bot Madrid 40:257-261

Boggs KW, Story JM (1987) The population age structure of spotted knapweed (Centaurea maculosa) in Montana. Weed Sci 35:194-198

Broennimann O, Treier UA, Müller-Schärer H, Thuiller W, Peterson AT, Guisan A (2007) Evidence of climatic niche shift during biological invasion. Ecol Lett 10:701-709

Brummitt RK (2004) Report of the Committee for Spermatophyta 54. Taxon 53:813-825

Crowe ML, Bourchier RS (2006) Interspecific interactions between the gall-fly Urophora affinis Frfld. (Diptera: Tephritidae) and the weevil Larinus minutus Gyll. (Coleoptera: Curculionidae), two biological control agents released against spotted knapweed, Centaurea stoebe L. ssp. micranthos. Biocontrol Sci Technol 16:417-430

Dostál J (1973) Preliminary notes on the subtribe Centaureinae. Acta Bot Acad Sci Hung 19:73-79

Dostál J (1976) Centaurea L. In Tutin TG, Heywood VH, Burges NA, Moore DM, Valentine DH, Walters SM, Webb DA (eds) Flora Europaea 4. Cambridge University Press, London, New York, pp 254-301

Dostál J (1989) Nová květena ČSSR 2. Academia Praha, Praha

Dostál J, Červenka M (1992) Velký klúč na určovanie vyššich rastlín 2. SPN, Bratislava

Emery SM, Gross KL (2005) Effects of prescribed fire on the demography of an invasive plant, spotted knapweed Centaurea maculosa. J Appl Ecol 42:60-69

Everitt B (1986) Cluster analysis. Ed. 2, Gower, Halsted Press, New York (reprint 2)

Futák J (1984) Fytogeografické členenie. In Bertová L (ed) Flóra Slovenska 4(1) (Appendix). Veda, VSAV, Bratislava

Garcia-Jacas N, Susanna A, Garnatje T, Villatersana R (2001) Generic delimitation and phylogeny of the subtribe Centaureinae (Asteraceae): a combined nuclear and chloroplast DNA analysis. Ann Bot (Oxford) 87:503-515

Garcia-Jacas N, Susanna A, Mozaffarian V, Ilarslan R (2000) The natural delimitation of Centaurea (Asteraceae: Cardueae): ITS sequence analysis of the Centaurea jacea group. Pl Syst Evol 223:185-199

Garcia-Jacas N, Uysal T, Romashchenko K, Suárez-Santiago VN, Ertuğrul K, Susanna A (2006) Centaurea revisited: A molecular survey of the Jacea group. Ann Bot (Oxford) 98:741-753

Goldblatt P, Johnson DE (2007) Index to plant chromosome numbers, 1979-. Missouri Botanical Garden, St. Louis, http://mobot.mobot.org/W3T/Search/ipen.html

Greuter W (2003) The Euro+Med treatment of Cardueae (Compositae) - generic concepts and required new names. Willdenowia 33:49-61

Greuter W, Agababian M, Wagenitz G (2005) Vaillant on Compositae - systematic concepts and nomenclatural impact. Taxon 54:149-174 
Greuter W, Wagenitz G, Agababian M, Hellwig FH (2001) Proposal to conserve the name Centaurea (Compositae) with a conserved type. Taxon 50:1201-1205

Gugler W (1907) Die Centaureen des Ungarischen Nationalmuseums. Ann Hist-Nat Mus Natl Hung 6:1-297

Guinochet M (1956) Sur l'existence d'une forme systématique normalement trisomique chez Centaurea paniculata L. Compt Rend Acad Sci Paris 243:2130-2132

Guinochet M (1957) Contribution à l'étude caryologique du genre Centaurea L. sens. lat. Bull Soc Hist Nat Afr Nord 48:282-300

Halverson K, Heard SB, Nason JD, Stireman JO (2008) Origin, distribution, and local co-occurrence of polyploid cytotypes in Solidago altissima (Asteraceae). Amer J Bot 95:50-58

Hardy OJ, Vanderhoeven S, De Loose M, Meerts P (2000) Ecological, morphological and allozymic differentiation between diploid and tetraploid knapweeds (Centaurea jacea) from a contact zone in the Belgian Ardenes. New Phytol 146:281-290

Hardy OJ, De Loose M, Vekemans X, Meerts P (2001) Allozyme segregation and inter-cytotype reproductive barriers in the polyploid complex Centaurea jacea. Heredity 87:136-145

Hill LM (1995) IOPB chromosome data 9. Newslett Int Organ Pl Biosyst 24:19-20

Hodálová I, Grulich V, Horová L, Valachovič M, Marhold K (2007) Occurrence of tetraploid and octoploid cytotypes of Senecio jacobaea ssp. jacobaea (Asteraceae) in Pannonia and the Carpathians. Bot J Linn Soc 154:231-242

Holmgren PK, Holmgren NH, Barnett LC (1990) Index Herbariorum. Part 1. The herbaria of the World. Regnum Veg 120:1-693

Holub J (1972) On correct generic names of Acrocentron Cass. and Acrolophus Cass. (Centaurea L. s.1.). Preslia 44:215-218

Holub J (1973) Some new nomenclatural combinations in Centaureinae (Asteraceae). Preslia 45:142-146

Holub J (1974) Some new nomenclatural combinations in Centaureinae (Asteraceae) II. Preslia 46:225-229

Hook PB, Olson BE, Wraith JM (2004) Effects of the invasive forb Centaurea maculosa on grassland carbon and nitrogen pools in Montana, USA. Ecosystems 7:686-694

Hufbauer RA, Sforza R (2008) Multiple introductions of two invasive Centaurea taxa inferred from cpDNA haplotypes. Diversity Distributions 14:252-261

Husband B (2000) Constraints on polyploid evolution: a test of the minority cytotype exclusion principle. Proc Biol Sci 267:217-223

Husband B (2004) The role of triploid hybrids in the evolutionary dynamics of mixed-ploidy populations. Biol J Linn Soc 82:537-546

Husband B, Sabara HA (2003) Reproductive isolation between autotetraploids and their diploid progenitors in fireweed, Chamerion angustifolium (Onagraceae). New Phytol 161:703-713

Keeler KH, Davis GA (1999) Comparison of common cytotypes of Andropogon gerardii (Andropogoneae, Poaceae). Amer J Bot 86:974-979

Kerner AJ (1872) Die Vegetations-Verhältnisse des mittleren und östlichen Ungarns und angrenzenden Siebenbürgens. Oesterr Bot Z 22:117-121

Klecka WR (1980) Discriminant analysis. Sage University Papers, Series: Quantitative Applications in the Social Sciences, no. 19. Sage, Beverly Hills

Koutecký P (2007) Morphological and ploidy level variation of Centaruea phrygia agg. (Asteraceae) in the Czech Republic, Slovakia and Ukraine. Folia Geobot 42:77-102

Koutecký P (2008) Taxonomická studie středoevropských zástupců Centaurea sect. Jacea (chrpa). [Taxonomic study of Central European taxa of Centaurea sect. Jacea (Knapweeds)]. Ph.D. Thesis, Faculty of Science, University of South Bohemia, České Budějovice

Krzanowski WJ (1990) Principles of multivariate analysis. Clarendon Press, Oxford

Legendre P, Legendre L (1998) Numerical ecology. Elsevier Science B.V., Amsterdam

Leitch IJ, Bennett MD (2004) Genome downsizing in polyploid plants. Biol J Linn Soc 82:651-663

Levin DA (1975) Minority cytotype exclusion in local plant populations. Taxon 24:35-43

Lihová J, Marhold K, Neuffer B (2000) Taxonomy of Cardamine amara (Cruciferae) in the Iberian Peninsula. Taxon 49:747-763

Lihová J, Tribsch A, Marhold K (2003) The Cardamine pratensis (Brassicaceae) group in the Iberian Peninsula: taxonomy, polyploidy and distribution. Taxon 52:783-802

Lihová J, Marhold K, Tribsch A, Stuessy TF (2004) Morphometric and AFLP re-evaluation of tetraploid Cardamine amara (Brassicaceae) in the Mediterranean. Syst Bot 29:134-146

Löve Á, Löve D (1961a) Some nomenclatural changes in the European flora I. Bot Not 114:33-47

Löve Á, Löve D (1961b) Chromosome numbers of Central and Northwest European plant species. Opera Bot 5:1-581 
Lövkvist B, Hultgård U-M (1999) Chromosome numbers in south Swedish vascular plants. Opera Bot $137: 1-42$

Lutgen ER, Rillig MC (2004) Influence of spotted knapweed (Centaurea maculosa) management treatments on arbuscular mycorrhizae and soil aggregation. Weed Sci 52:172-177

Mądalski J, Ciaciura M (1972) Centaurea L. In Pawłowski B, Jasiewicz A, Browicz K, Mądalski J, Zarzycki K (eds) Flora Polska, Rośliny naczyniowe polski i ziem ościennych 13. Państwowe wydawnictwo naukove, Warszawa, Kraków, pp 35-91

Marhold K (1996) Multivariate morphometric study of the Cardamine pratensis group (Cruciferae) in the Carpathian and Pannonian area. Pl Syst Evol 200:141-159

Marhold K (1999) Taxonomic evaluation of the tetraploid populations of Cardamine amara (Brassicaceae) from the Eastern Alps and adjacent areas. Bot Helv 109:67-84

Marhold K, Hindák F (1998) Zoznam nižšich a vy̌šsich rastlín Slovenska - Checklist of non-vascular and vascular plants of Slovakia. VEDA, Vydavatel'stvo Slovenskej akadémie vied, Bratislava

Marks GE (1954) An aceto-carmine glycerol jelly for use in pollen fertility counts. Stain Technol 29:277

Meusel H, Jäger EJ (1992) Vergleichende Chorologie der zentraleuropäischen Flora 3. G. Fischer, Jena, Stuttgart, New York

Moore RJ, Frankton C (1954) Cytotaxonomy of three species of Centaurea adventive in Canada. Canad J Bot 32:182

Morefield JD, Schaack CG (1985) Chromosome number reports 86. Taxon 34:159-164

Murín A. (1960) Substitution of cellophane for glass covers to facilitate preparation of permanent squashes and smears. Stain Technol 35:351-353

Nagel J (2000) [Chromosome number reports] In: Ochsmann J, Morphologische und molekularsystematische Untersuchungen an der Centaurea stoebe L. - Gruppe (Asteraceae-Cardueae) in Europa. Diss Bot 324:233-234

Nakagawa M (2006) Ploidy, geographical distribution and morphological differentiation of Parasenecio auriculata (Senecioneae, Asteraceae) in Japan. J Pl Res 119:51-61

Niklfeld H (1971) Bericht über die Kartierung der Flora Mitteleuropas. Taxon 20:545-571

Ochsmann J (1999) Chromosomenzahlen einiger europäischer Centaurea-Sippen (Asteraceae). Haussknechtia 7:59-65

Ochsmann J (2000) Morphologische und molekularsystematische Untersuchungen an der Centaurea stoebe L. - Gruppe (Asteraceae-Cardueae) in Europa. Diss Bot 324

Osborn TC, Pires JCH, Birchler JA, Auger DL, Chen ZJ, Lee H-S, Comai L, Madlung A, Doerge RW, Colot V, Martienssen RA (2003) Understanding mechanisms of novel gene expression in polyploids. Trends Genet 19:141-147

Otto F (1990) DAPI staining of fixed cells for high-resolution flow cytometry of nuclear DNA. In Crissman HA, Darzynkiewicz Z (eds), Methods in cell biology 33. Academic Press, New York, pp $105-110$

Perný M, Tribsch A, Stuessy TF, Marhold K (2005). Taxonomy and cytogeography of Cardamine raphanifolia and C. gallaecica (Brassicaceae) in the Iberian Peninsula. Pl Syst Evol 254:69-91

Perry LG, Thelen GC, Ridenour WM, Weir TL, Callaway RM, Paschke MW, Vivanco JM (2005) Dual role for an allelochemical: $( \pm)$-catechin from Centaurea maculosa root exudates regulates conspecific seedling establishment. $J$ Ecol 93:1126-1135

Podani J (2001) SYN-TAX 2000. Computer programs for data analysis in ecology and systematics. User's manual. Scientia Publishing, Budapest

Powell AM, Kyhos DW, Raven PH (1974) Chromosome numbers in Compositae 10. Amer J Bot 61:909-913

Probatova NS, Rudyka EG, Sokolovskaya AP (1996) Chromosome numbers in synanthropic plants from the Russian Far East. Bot Zhurn 81(5):98-101

Prodan J, Nyárády EI (1964) Centaurea. In Săvulescu T (ed), Flora Republicii Populare Romîne 9. Editura Academiei Republicii Populare Romîne, Bucuresti, pp 785-951

Rowley GD (2007) Cytotypes: a case for infraspecific names. Taxon 56:983

SAS Institute (2000) SAS OnlineDoc ${ }^{\circledR}$, version 8 (available online). SAS Institute, Cary

Schols P, Dessein S, D'Hondt C, Huysmans S, Smets E (2002) Carnoy, a new digital measurement tool for palynology. Grana 41:124-126

Schönswetter P, Suda J, Popp M, Weiss-Schneeweiss H, Brochmann Ch (2007) Circumpolar phylogeography of Juncus biglumis (Juncaceae) inferred from AFLP fingerprints, cpDNA sequences, nuclear DNA content and chromosome numbers. Molec Phylogen Evol 42:92-103

Schubert R, Vent W (1976) Rothmaler Exkursionflora für die Gebiete der DDR und BRD 4. Volk und Wissen Volkseigener Verlag, Berlin 
Siljak-Yakovlev S, Solic ME, Catrice O, Brown SC, Papes D (2005) Nuclear DNA content and chromosome number in some diploid and tetraploid Centaurea (Asteraceae: Cardueae) from the Dalmatia Region. Pl Biol 7:397-404

Simon T (2000) A magyarországi edényes flóra határozója. Nemzeti Tankönyvkiadó, Budapest

Skalińska M, Piotrowicz M, Czapik R, et al (1959) Further studies in chromosome numbers of Polish Angiosperms (Dicotyledons). Acta Soc Bot Polon 28:487-529

Sneath PAH, Sokal RR (1973) Numerical taxonomy. Principles and practice of numerical classification. W. H. Freeman and company, San Francisco

Soják J (1972) Nomenklatorické poznámky (Phanerogamae). Čas Nár Mus Odd Přír 140:127-134

Soltis DE, Soltis PS, Tate JA (2003) Advances in the study of polyploidy since Plant speciation. New Phytol 161:173-191

Soltis DE, Soltis PS, Pires JCH, Kovarik A, Tate JA, Mavrodiev E (2004) Recent and recurrent polyploidy in Tragopogon (Asteraceae): cytogenetic, genomic and genetic comparisons. Biol J Linn Soc 82:485-501

Soltis DE, Soltis PS, Schemske DW, Hancock JF, Thompson JN, Husband BC, Judd WS (2007) Autopolyploidy in angiosperms: have we grossly underestimated the number of species? Taxon 56:13-30

Soó R (1970) A magyar flóra és vegetáció rendszertani növényföldrajzi kézikönyve 4. Akadémiai Kiadó, Budapest

Španiel S (2007) [New records in Centaurea]. In Marhold K, Mártonfi P, Mered'a P, Mráz P (eds), Chromosome number survey of the ferns and flowering plants of Slovakia. VEDA, Bratislava, pp 179, 181-183

Stace C (1991) New flora of the British Isles. Cambridge University Press, Cambridge

Štepánek J (2002) Centaurea L. In Kubát K, Hrouda L, Chrtek J, Kaplan Z, Kirschner J, Štěpánek J (eds) Klíč ke květeně České republiky. Academia, Praha, pp 673-676

Štepánek J, Koutecký P (2005) Centaurea L. In Slavík B, Štepánková J (eds) Květena České republiky 7. Academia, Praha, pp 426-449

Story JM, Smith L, Good WR (2001) Relationship among growth attributes of spotted knapweed (Centaurea maculosa) in Western Montana. Weed Technol 15:750-761

Suda J (1998) Taxonomická problematika rodu Oxycoccus v České republice se zvláštním zřetelem k území Šumavy. Zpr Čes Bot Společ 32(1997):189-195

Suda J, Lysák MA (2001) A taxonomic study of the Vaccinium sect. Oxycoccus (Hill) W. D. J. Koch (Ericaceae) in the Czech Republic and adjacent territories. Folia Geobot 36:303-320

Suda J, Weiss-Schneeweiss H, Tribsch A, Schneeweiss GM, Trávníček P, Schönswetter P (2007) Complex distribution patterns of di, tetra-, and hexaploid cytotypes in the European high mountain plant Senecio carniolicus (Asteraceae). Amer J Bot 94:1391-1401

Susanna A, Garcia-Jacas N, Soltis DE, Soltis PS (1995) Phylogenetic relationships in tribe Cardueae (Asteraceae) based on ITS sequences. Amer J Bot 82:1056-1068

Taylor RL, Taylor S (1977) Chromosome numbers of vascular plants of British Columbia. Syesis 10:125-138

Thorpe RS (1976) Biometric analysis of geographic variation and racial varietes. Biol Rev 51:407-452

Trávníček B, Lysák AM, Č́íhalíková J, Doležel J (2004) Karyotaxonomic study of the genus Pseudolysimachion (Scrophulariaceae) in the Czech Republic and Slovakia. Folia Geobot 39:173-203

Van Dijk P, Bakx-Schotman T (1997) Chloroplast DNA phylogeography and cytotype geography in autopolyploid Plantago media. Molec Ecol 6:345-352

Vanderhoeven S, Hardy O, Vekemans X, Lefèbre C, De Loose M, Lambinon J, Meerts P (2002) A morphometric study of populations of the Centaurea jacea complex (Asteraceae) in Belgium. Pl Biol 4:403-412

Visjulina OD (1965) Flora URSR 12. Naukova Dumka, Kiiv

Wagenitz G (1987) Centaurea. In Hegi G (ed) Illustrierte Flora von Mitteleuropa 6/2: Nachträge, Berichtigungen und Ergänzungen zum Nachdruck der 1. Aufl. von Band VI/2 (1928/9). Ed. 2, Parey, Berlin, pp 1405-1413

Wagenitz G, Hellwig FH (1996) Evolution of characters and phylogeny of the Centaureinae. In Hind DJN, Beentje HJ (eds), Compositae: Systematics. Proceedings of the International Compositae Conference, Kew, 1994. Royal Botanical Gardens, Kew, pp 491-510

Wagner J (1910) A magyarozágy Centaureák ismertetése (Centaureae Hungariae). Budapest

Wendel JF (2000) Genome evolution in polyploids. Pl Molec Biol 42:225-249

Wendel J, Cronn RC, Johnston JS, Price HJ (2002) Feast and famine in plant genomes. Genetica 115:37-47

Záborský J (1970) [Reports in Cyanus] In Májovský et al. Index of chromosome numbers of Slovakian flora (Part 1). Acta Fac Rerum Nat Univ Comeniae, Bot 16:9

Received: 17 January 2008 /Revised: 15 April 2008 /Accepted: 20 April 2008 /

Published online: 21 August 2008 